\title{
How to Deal with Radiologically Contaminated Vegetation
} (U)

by

\section{E. W. Wilde}

Westinghouse Savannah River Company

Savannah River Site

Aiken, South Carolina 29808

C. E. Murphy

R. T. Lamar

M. J. Larson

\section{MASTER}

DOE Contract No. DE-AC09-89SR18035

This paper was prepared in connection with work done under the above contract number with the U.S.

Department of Energy. By acceptance of this paper, the publisher and/or recipient acknowledges the U.S. Government's right to retain a nonexclusive, royalty-free license in and to any copyright covering this paper, along with the right to reproduce and to authorize others to reproduce all or part of the copyrighted paper. 


\section{DISCLAIMER}

This report was prepared as an account of work sponsored by an agency of the United States Government. Neither the United States Government nor any agency thereof, nor any of their employees, makes any warranty, express or implied, or assumes any legal liability or responsibility for the accuracy, completeness, or usefulness of any information, apparatus, product, or process disclosed, or represents that its use would not infringe privately owned rights. Reference herein to any specific commercial product, process, or service by trade name, trademark, manufacturer, or otherwise does not necessarily constitute or imply its endorsement, recommendation, or favoring by the United States Government or any agency thereof. The views and opinions of authors expressed herein do not necessarily state or reflect those of the United States Government or any agency thereof.

This report has been reproduced directly from the best available copy.

Available to DOE and DOE contractors from the Office of Scientific and Technical Information, P.O. Box 62, Oak Ridge, TN 37831; prices available from (615) 576-8401.

Available to the public from the National Technical Information Service, U.S. Department of Commerce, 5285 Port Royal Road, Springfield, VA 22161. 


\section{DISCLAMMIER}

Portions of this document may be illegible in electronic image products. Images are produced from the best available original document. 
WSRC-TR-96-0125

\section{HOW TO DEAL WITH RADIOLOGICALLY CONTAMINATED VEGETATION}

by

E. W. Wilde, C.E. Murphy, R. T. Lamar and M. J. Larsen

Prepared for the Department of Energy Office of Technology Development, Landfill Stabilization Focus Area

Approved by: D.B. Moore-Shedrow

Environmental Sciences Section

Savannah River Technology Center

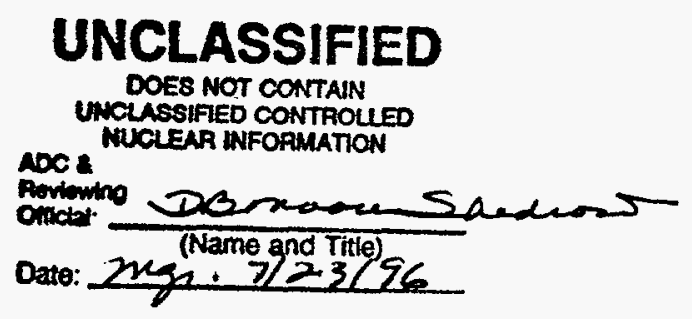


WSRC-TR-96-0125

HOW TO DEAL WITH RADIOLOGICALLY CONTAMINATED VEGETATION

by

E. W. Wilde, C.E. Murphy, R. T. Lamar and M. J. Larsen

Prepared for the Department of Energy Office of Technology Development, Landfill Stabilization Focus Area

Approved by: D.B. Moore-Shedrow

Environmental Sciences Section

Savannah River Technology Center 
WSRC-TR-96-0125

\subsection{INTRODUCTION}

This report describes the findings from a literature review conducted as part of a Department of Energy, Office of Technology Development Biomass Remediation Task (TTP SR1-6-LF-51C). The principal objective of this project is to develop a process or group of processes to treat radiologically contaminated vegetation in a manner that minimizes handling, processing, and treatment costs.

Contaminated, woody vegetation growing on waste sites at SRS poses a problem to waste site closure technologies that are being considered for these sites. It is feared that large sections of woody vegetation (logs) can not be buried in waste sites where isolation of waste is accomplished by capping the site. Logs or large piles of woody debris have the potential of decaying and leaving voids under the cap. This could lead to cap failure and entrance of water into the waste. Large solid objects could also interfere with treatments like "in situ" mixing of soil with grout or other materials to encapsulate the contaminated sediments and soils in the waste sites.

The principal radionuclides of concern are cesium (in the form of Cs-137, half life-30 yr.) and Strontium ( $\mathrm{Sr}-90$, half life-29 yr.). Cesium, a monovalent cation, is similar to potassium and tends to accumulate in the muscle tissue of mammals following exposure. Strontium, a divalent cation, acts similarly to calcium and accumulates in bone tissue.

Several waste sites at the SRS contain at least some woody vegetation. It has been estimated that approximately 40,000 cubic yards of contaminated woody vegetation is within the boundaries of these waste sites. This vegetation consists of approximately $60 \%$ conifers, $20 \%$ hardwoods and $20 \%$ shrubs and grasses. These waste sites are scheduled for CERCLARCRA closure under the Federal Facilities Agreement between DOE, EPA Region IV, and the state of South Carolina.

Optimal disposal of the wood includes considerations of volume reduction, treatment of the radioactive residue resulting from volume reduction, or confinement without volume reduction. Volume reduction consists primarily of removing the carbon, oxygen, and hydrogen in the wood, leaving an ash that would contain most of the contamination. The only contaminant that would be released by volume reduction would by small amounts of the radioactive isotope of hydrogen, tritium.

Stabilization would consist of putting the woody vegetation, with or without volume reduction, into a matrix which would limit transport of the radioactive contaminants from the final repository. This repository could include the E-Area Vaults, the low-level waste burial ground, a vitrification facility or in the capped or the stabilized waste site. Treatments that would allow the contaminated wood or the residue remaining after volume reduction to be stabilized at the waste site could reduce the potential personnel exposure and cost related to transporting the material to another repository. 
Stabilization without volume reduction could be accomplished by placing the relatively low-level wood in a matrix that would not degenerate as the wood decayed. The matrix would also have to have the capacity to retain its physical integrity and immobilize the contaminants as the wood decays. It is possible that stabilization can be obtained by taking advantage of the fact that wood immobilized in a reducing (anoxic) environment would decay very slowly and might retain its stability for centuries.

The following sections will describe the waste sites at SRS which contain contaminated vegetation and are potential candidates for the technology developed under this proposal. The description will provide a context for the magnitude of the problem and the logistics of the alternative solutions that are evaluated later in the review. 


\subsection{DESCRIPTION OF SITES AT SRS REQUIRING REMEDIATION}

Most of the waste sites at SRS that have been identified as having significant amounts of radiologically contaminated vegetation have a history of receiving radioactive, liquid effluents via seepage basins that were used for the disposal of low-level radioactive, liquid effluents. The water seeped through the earthen floor of the basins. This effectively removed a significant part of the radioactive contamination before the water reached the groundwater. These radionuclides were retained by the first few meters of soil under the basins. Later, this became the source of radionuclides for the vegetation which invaded the inactive waste site. The exception is the HP-52 Outfall which was contaminated by a spill from a high-level waste tank in the H-Area Tank Farm.

\subsection{Old F-Area Seepage Basin (904-49G)}

\subsubsection{General Description}

The Old F-Area Seepage Basin is located just northeast of the F-Area perimeter security fence and north of 221-F building. Midpoint coordinates of the basin are $33.17279^{\circ} \mathrm{N}$ latitude and $81.404820^{\circ} \mathrm{W}$ longitude. The rectangular basin, $59 \mathrm{~m}$ long by $91 \mathrm{~m}$ wide, has an area of approximately $5,370 \mathrm{~m}^{2}$. The area is surrounded by an exclusion fence which contains an area of approximately $8,960 \mathrm{~m}^{2}$. The basin was excavated in the native soil which was used to construct a low dike around the basin. The excavation resulted in a narrow trench which runs in a east-west direction from the intake at the southwest corner of the basin. At the southeast corner of the basin this trench empties into a broader trench which flows westward to the outlet at the northwest corner.

At present, the Basin surface has been revegetated to a mixed forest of pine and various hardwood species. A small wet-weather pond, bordered with cattails (Typha) and other emergent macrophytes has formed in the deepest part of the old seepage basin. The forest canopy has closed over most of the basin and the forest floor contains only a sparse understory of shrubs and herbs. A corridor of shrubs and herbs remains between the main entrance gate and the wet weather pond on the west end of the basin.

The Old F-Area Seepage Basin was the first basin constructed in this area and received between 35 and 52 million liters of waste water from November 1954 to midMay 1955. The source of the waste water included evaporator overheads, laundry waste water, and other discharges of unknown constituent content. Since 1955, the basin has been used intermittently to divert rainfall runoff and process effluents from NPDES Outfall F-2. This includes between 14,000 to 21,000 liters of spent etching solution $\left(6 \mathrm{M} \mathrm{HNO}_{3}\right)$ used to etch depleted uranium during manufacturing of reactor targets. At the present time rainfall and process effluents are no longer diverted to the Old F-Area Seepàge Basin. 


\subsubsection{Radionuclide Concentrations and Inventories}

Several samplings of vegetation and soils have been made to determine the radionuclides present at the site (CORR-87-0117 1987, DPST-85-692 1985). Table 1. summarizes the findings of these investigations. A more thorough investigation was carried out in 1994 to determine the level of contamination of the vegetation (Murphy, 1994). The resulting concentrations in wood and leaves is shown in Table 2. Measurements were not made for lodine-129 in this study. lodine-129 was known to be released to the basin and earlier investigations detected lodine-129 in the soil but was not in the vegetation. The rationale not to measure this radionuclide was based on the low level of $1-129$ found in the soil and the low uptake of iodine by vegetation. The combination of these factors suggested that any attempt to measure $1-129$ would be unlikely to be successful.

An inventory of metals and radionuclide contaminants can be calculated by multiplying the concentrations measured in the vegetation by the mass of vegetation inside the basin enclosure. Since the concentrations in leaves and wood differ for some radionuclides, a better estimate will result from a separate estimate of the mass of leaves and wood.

The mass of wood inside the exclusion fence of the basin was estimated by taking a $100 \%$ tally of the trees by diameter class. The diameter class data was converted to mass of the entire tree with regressions based on a study of southern pine biomass by Metz and Wells (1965). The product of the basal area of the tree and the height was fit to the total mass of the trees. The adjusted $R^{2}$ for the regression was 0.99 The logarithm of the basal area-height product was regressed against the logarithm of the percentage of leaf mass. The $\mathrm{R}^{2}$ of this regression was 0.95 . The calculations estimated a total mass of 0.8 metric tons (2.5/0.4) leaves and 15.0 metric tons (22.0/7.1) wood. This leads to the total activity of radionuclide shown in Table 3.

Two potentially important characteristics of the activity found in the basin, not obvious from the above description, are the spatial distribution of the contamination and the inventory in the vegetation relative to that in the soil of the basin. The highest levels of contamination are found in two areas. The area near the inlet is relatively high in contamination and the highest contamination is in the trees growing near the wet weather pond on the west end of the basin.

Table 1. Radionuclide Detected in Old F-Area Seepage Basin. Detected In

CONTAMINANT

Cs-137

Pu-239,240

$\mathrm{U}-238$

Sr-90

I-129 RELEASES

$x$

$\mathrm{X}$

$\mathbf{x}$

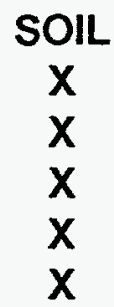

VEGETATION

$\mathbf{X}$

$\mathbf{X}$ 
Table 2. Geometric Mean, $95 \%$ Confidence Limits of Tree Leaf and Wood Radionuclide Concentration inside Fence at the Old F-Area Seepage Basin and Mean Concentration of Samples from outside the Fenced Area (pCi/gm).

$\begin{array}{cccccc}\text { Vegetation Type } & \text { Sr-90 } & \text { Cs-137 } & \begin{array}{c}\text { Pu-239, } \\ 240\end{array} & \text { Pu-238 } & \text { U-238 } \\ \text { Leaves } & & & & \\ \quad \text { Mean } & 0.95 & 11.1 & 0.0051 & 0.0018 & 0.158 \\ \text { Upper 95 } & 2.83 & 26.6 & 0.0141 & 0.0043 & 0.411 \\ \text { Lower 95 } & 0.32 & 4.67 & 0.0019 & 0.0007 & 0.061 \\ \text { Mean Outside } & 0.58 & 2.8 & 0.0010 & 1.1 \mathrm{E}-05 & 0.043 \\ \text { Fence } & & & & & \\ & & & & & \\ \text { Wood } & & & & & \\ \text { Mean } & 0.92 & 6.7 & 0.0007 & 0.0002 & 0.020 \\ \text { Upper 95 } & 2.53 & 16.0 & 0.0047 & 0.0017 & 0.094 \\ \text { Lower 95 } & 0.34 & 2.8 & 0.0001 & 1.4 \mathrm{E}-05 & 0.004 \\ \text { Mean Outside } & 0.81 & 0.8 & 0.0008 & 0.0035 & 0.025\end{array}$

Fence

Table 3. Total Inventory of Radionuclides in the Vegetation (mCi)

$\begin{array}{lcccccc} & \text { Sr-90 } & \text { Cs-137 } & \begin{array}{c}\text { Pu-239, } \\ 240\end{array} & \text { Pu-238 } & \text { U-238 } & \text { Total } \\ \text { Mean } & 14.4 & 108 & 0.015 & 0.0036 & 0.41 & 123 \\ \text { Lower 95 } & 2.4 & 20 & 0.001 & 0.0003 & 0.04 & 23 \\ \text { Upper 95 } & 61.5 & 408 & 0.133 & 0.0467 & 2.96 & 473\end{array}$


An estimate of the relative activity in trees and soil can be made by using the release estimates made in DPST-85-692 (1985), under the assumption that the decay corrected total of the release still resides in the basin. The estimated inventories are $20 \mathrm{mCi}$ of Pu-239, 240 and $150 \mathrm{mCi}$ of $\mathrm{Sr}-90$. The resulting ratios of vegetation to other waste site inventories are respectively $7.5 \times 10^{-7}$ and $9.6 \times 10^{-5}$. In either case, the inventory in the vegetation is very small compared to that estimated to be in the soil. This means that disposal of the vegetation at the existing waste site will not add a significant amount of contamination to the waste site.

2.2 SRL Seepage Basins (904-51F1, 904-53G2, 904-54G, 904-55G)

2.2.1 General Description

The four Seepage Basins are located south of Road A-1 and west of Road D-1 in the northwestern section of SRS. The approximate coordinates of the southeast corner of Basin 1 are $33.3451280 \mathrm{~N}$ and $81.7335050 \mathrm{~W}$. The basins are rectangular in shape and were constructed by removing the earth from within the basins to form the surrounding dikes. The construction of Basins 1,2, and 3 principally involved excavation of natural soils and the construction of limited perimeter dikes. The construction of Basin 4 required substantial filling at the north end (adjacent to Tims Branch) to achieve both the basin bottom and the dike crest elevation. The dimensions of the individual basins are given in Table 4.

Table 4. Dimensions and Approximate Capacity of the SRL Seepage Basins.

$\begin{array}{ccc}\text { Basin } & \text { Dimensions }(\mathrm{L} \times \mathrm{W} \times \mathrm{D}, & \text { Volume }\left(\mathrm{m}^{3}\right) \\ & \mathrm{m}) & \\ 1 & 40 \times 19 \times 2.0 & 1,520 \\ 2 & 40 \times 40 \times 2.0 & 3,200 \\ 3 & 53 \times 38 \times 2.7 & 5,440 \\ 4 & 94 \times 46 \times 3.4 & 14,700\end{array}$

Waste-water entered Basin 1 by a pipeline from SRL. The water overflowing Basin 1 entered Basin 2 and then sequentially into Basins 3 and 4 when the water flow was greater than the infiltration capacity of the preceding basins). Waste-water seldom entered Basin 4 because the infiltration capacity of the first three basins equaled or exceeded the input volume. Water entering the sediment at the base of the water column appears to have infiltrated downward, toward the ground water. There is no evidence that water from the basins reached Tims Branch, a small nearby stream down gradient from Basin 4.

Basins 1 and 2 have no emergent vegetation growing on the basin bottom. The bottom of these basins has generally remained covered with water, even after discharges to the basins stopped. The slopes of the basin dikes are densely covered with young trees. Most of the trees were less than ten years old at the time of the latest sampling 
(June 1991). The majority of the trees are deciduous angiosperms (hardwoods), with a few scattered conifers (pines).

The bottom of Basin 3 also lacks any emergent vegetation. At the time of this study, the basin bottom was intermittently covered with water. The vegetative cover on the slopes of the dikes surrounding Basin 3 contains less woody vegetation with a majority of the surface covered by grasses and herbaceous vegetation. The woody vegetation is largely hardwood trees with some scattered pines.

Basin 4 is the only basin that has trees growing on the bottom of the basin. Most of the basin is covered by a dense stand of young pines. A few hardwoods are also growing in the basin. The age of the trees was estimated to be less than ten years at the time of this study. The edge of the basin was characterized by a less dense stand of the same species. There is a small stand of older pine trees, estimated age 25 to 35 years, growing on the high dike separating the north side of Basin 4 from Tims Branch.

The first two basins were placed into operation in 1954. Basins 3 and 4 were added in 1958 and 1960, respectively. SRL used the seepage basins to dispose of low-level radioactive liquid wastes. Pipes that tied into the low-level drains in the laboratories transferred the waste into one of four underground tanks. When one of the tanks accumulated approximately $20 \mathrm{~m}^{3}$ of waste, the contents were sampled. If the analysis of the wastewater indicated concentrations not exceeding $100 \mathrm{~d} / \mathrm{m} / \mathrm{mL}$ alpha or 50 $\mathrm{d} / \mathrm{m} / \mathrm{mL}$ beta-gamma, the waste-water was discharged to the seepage basins. If concentrations exceeded these limits, the wastewater was sent to another facility.

Releases to the SRL Seepage Basins stopped after 1982. During the 28-year loading history, approximately $130,000 \mathrm{~m}^{3}$ of water were discharged to the basins. Table 5 lists the radioactive releases between 1958 and 1980. An estimate of the total discharge of other contaminants was made on the basis of the concentrations in the low-level waste stream sampled during October, 1982. The loadings of selected metals are listed in Table 6.

\subsubsection{Radionuclide Concentrations and Inventories}

In the summer of 1990, measurements were made of wood and leaf activity on thirty trees growing in or adjacent to the basins (unpublished data). Table 7. summarizes the concentrations of the radionuclides detected in the trees. The mass of wood associated with each basin was determined by a $100 \%$ tally of diameters and heights of all trees above 1 inch in diameter at 1.5 meters. Stem wood volume was estimated from Monk (1966) for smaller trees and from Wahlenberg (1960) for larger trees. Wood density was taken from Koch (1972). The mass associated with each basin was 3.5, 3, 1,11 metric tons, dry weight respectively for basins $1,2,3$, and 4 . The inventory of radionuclides was calculated by multiplying the mass of the trees associated with a basin and the average concentration measured in a sample of the same trees. The results are shown in Table 8. 
Table 5. Radioactive Releases to the SRL Seepage Basins from 1958 to 1980 (Bransford et al. (1988))

\begin{tabular}{lc} 
Radionuclide & Released Activity (Ci) \\
\cline { 2 - 2 } $3 \mathrm{H}$ & 105 \\
$89,90 \mathrm{Sr}$ & 0.4 \\
$137 \mathrm{Cs}$ & 4.7 \\
$\mathrm{Natural}$ & 0.022 \\
$238 \mathrm{Pu}$ & 0.009 \\
$239 \mathrm{Pu}$ & 0.003 \\
$241 \mathrm{Am}$ & 0.001 \\
$242,244 \mathrm{Cm}$ & 0.001 \\
$103,106 \mathrm{Ru}$ & 1.4 \\
$60 \mathrm{Co}$ & 0.1 \\
$141,144 \mathrm{Ce}$ & 2.7 \\
Alpha (unidentified) & 4.2 \\
Beta-gama & 10.6
\end{tabular}


Table 6. Estimated Releases of Selected Metals (Bransford et al. 1988)

$\begin{array}{lr}\text { Element } & \text { Release (kg) } \\ \text { Barium } & 64 \\ \text { Chromium } & 1,220 \\ \text { Mercury } & 26 \\ \text { Magnesium } & 810 \\ \text { Manganese } & 438 \\ \text { Nickel } & 670 \\ \text { Lead } & 515 \\ \text { Zinc } & 219\end{array}$


WSRC-TR-96-0125

Table 7. Mean Vegetation Concentrations in SRL Basins (pCi/gm-dry)

\begin{tabular}{|c|c|c|c|c|c|c|c|}
\hline $\begin{array}{c}\text { Basin/Sam } \\
\text { ple Type } \\
\text { Leaf }\end{array}$ & Sr-90 & Co-60 & Cs-137 & Pu-238 & Pu-239 & $\mathrm{Cm}-244$ & Am-241 \\
\hline$\overline{\text { Mean }}$ & 81 & 0.19 & 51.6 & $9.18 E-04$ & 1.61E-03 & $1.03+00$ & $2.35 \mathrm{E}-03$ \\
\hline $\begin{array}{c}\text { Lower } \\
(5 \%)\end{array}$ & 10 & 0.03 & 0.1 & 5.63E-05 & 9.91E-05 & $3.47 \mathrm{E}-02$ & $-6.11 E-04$ \\
\hline $\begin{array}{l}\text { Upper } \\
(95 \%)\end{array}$ & 259 & 0.55 & 179.3 & $4.18 E-03$ & $9.20 \mathrm{E}-03$ & $5.14 \mathrm{E}+00$ & 4.92E-03 \\
\hline Wood & & & & & & & \\
\hline Mean & 72 & 0.22 & 17.9 & $4.21 E-04$ & $8.49 \mathrm{E}-04$ & 7.83E-01 & $9.11 E-04$ \\
\hline
\end{tabular}


Table 8. Inventory of Radionuclides in the Vegetation Growing In and Adjacent to the SRL Seepage Basin (mCi).

Radionuclide

Sr-90

Co-60

Cs-137

Pu-238

Pu-239,240

$\mathrm{Cm}-244$

Am-241
Inventory

6.96e-01

9.89e-04

$6.13 e-02$

$1.57 \mathrm{e}-06$

4.31e-06

5.10e-03

$2.41 e-05$ 
The inventory of radionuclides under the basins can be estimated from sediment-core measurements. Shelby tube samplers bored five $20 \mathrm{ft}$. sample cores from the bottom of each basin, a total of twenty cores. The top $2 \mathrm{ft}$ of each Shelby sampler was cut into 3inch segments which were removed from the tube segments in the field. Below the top $2 \mathrm{ft}, 3-\mathrm{ft}$. intervals were used for analysis. A total of 280 sediment samples were collected.

With a few exceptions, the concentration of all the contaminants measured in both the vegetation and the sediments show a marked decrease in concentration with distance from the surface. This is expected if these radionuclides and metallic elements are strongly absorbed by the sediments. In many cases, a straight line relationship is found between concentration and depth when the concentration of a radionuclide or a metal collected at a particular depth is plotted against depth in logarithmic coordinates. The inventory for an individual basin was calculated by multiplying the basin area times the average integrated concentration over depth of the five cores taken in that basin. The inventories shown in Table 9. are the sum of the inventories for the four basins.

As in the Old F-Area Basin, the inventory of activity in the vegetation is small compared to the inventory in the sediments. Therefore, disposing of the vegetation or the residues of treating the vegetation in the closed waste site will have little impact on the amount of activity that will be left on the site. 
Table 9. Estimated Inventory of Radionuclide in the Sediments Under the SRL Seepage basins and the Ratio (Vegetation/Sediment) of Inventories,.

Radionuclide

Am-241

Cs-137

Co-60

$\mathrm{Cm}-243,244$

Sr-90

Pu-238

Pu-239
Total Quantity (Ci)

1.1687

35.565

0.69074

13.1399

20.2401

0.69826

2.8845
Vegetation/Sediment Ratio

2.06E-05

1.72E-03

$1.43 \mathrm{E}-03$

3.88E-04

3.44E-02

2.25E-06

1.49E-06 


\subsection{H-Area Retention Basin (281-3H)}

\subsubsection{General Description}

The H-Area Retention Basin is located adjacent to Road E, several hundred feet west of the southwest corner of Road E and Road 4. The northwest corner of the basin is at approximately $33.281934^{\circ} \mathrm{N}$ latitude and $81.64801^{\circ} \mathrm{W}$ longitude. The earthen, unlined basin was designed for temporary, emergency storage of potentially contaminated cooling water from the chemical separations process and storm sewer drainage. The basin is approximately $61 \times 36.6 \times 2.1$ meters with a volume of $4688 \mathrm{~m}^{3}$.

The basin was in operation from 1955 to 1972 . Both the recirculated and segregated cooling water systems in the separations area are monitored for any contamination from leaks in the cooling coils of process vessels containing activity. During the operating history of the basin, when any significant contamination was detected, the water was diverted to the retention basin. Further tests were conducted to determine if the water could be released to the environment or needed treatment. As the water was temporarily stored in the basin, some seeped into the soil. The basin is reported to have overflowed to the south to the outfall of a stream draining to Four-Mile Branch, spreading contamination into the forest along the creek. The soil berm around the basin is suspected to be contaminated since the soil in the berm was excavated from the basin bottom in 1979 .

At the time when this basin and an adjacent retention basin were replaced, the material from the bottom of one of the old basins was excavated and placed in an elongated pile on the western side of the existing old basin. The area previously containing the excavated basin is now occupied by a new lined retention basin. The soil pile and the unexcavated, old basin are surrounded by a fence.

Vegetation has invaded the edge and berm of the retention basin and the surface of the soil pile. Trees are prevented from growing in the basin by standing water. The basin contains water most of the year but may dry out during periods of prolonged drought.

\subsubsection{Radionuclide Concentrations and Inventories}

Soil surveys done in 1979 detected Cs-137, Pu-238, and Sr-90. Vegetation

measurements done at about the same time detected Cs-137 and Sr-90. More detailed measurements of vegetation concentrations are being done at the present time as part of an action to remove the vegetation from the site. The results of the earlier survey are summarized in Table 10. 
Table10. Estimated Inventory of Selected Radionuclides (Ci) in the H-Area Retention Basin

$\begin{array}{cccc}\text { Isotope } & \text { Soil Inventory } & \begin{array}{c}\text { Trees Inside } \\ \text { Fence }\end{array} & \begin{array}{c}\text { Trees Outside } \\ \text { Fence }\end{array} \\ \text { Pu-238 } & 0.35-0.5 & - & - \\ \text { Cs-137 } & 8.5-10.0 & 0.03 & 0.0001 \\ \text { Sr-90 } & 2.5-3.5 & 0.05 & 0.0009\end{array}$

* Estimated from the results of the 1979 vegetation radiation survey and the 1996 Savannah River Forest Station estimate of wood mass. 


\subsection{Warner's Pond}

Warner's Pond is located near the northwest corner of the intersection of SRS Road E and Road 4. The unit is located approximately $50 \mathrm{~m}$ north of Road $E$ and $50 \mathrm{~m}$ east of Road 4. It is adjacent to the H-Area Tank Farms and across from the lined H-Area Retention Basin.

The following description of the history and present condition of Warner's Pond is taken from the Removal Site Evaluation Report for Warner's Pond (WSRC-RP-951534). Warner's Pond was created in 1956 as an emergency holding pond to receive contaminated cooling water from the $\mathrm{H}$-Area Canyon Building. Contaminated cooling water was released to the pond in 1956, 1960, and 1965. The 1965 release was estimated to contain $300 \mathrm{Ci}$ of activity. On all three occasions, when waste water entered Warner's Pond it was diverted to the H-Area Retention Basins. In 1966 the Warner's Pond dam was broken, the pond was drained and backfilled with two feet of soil, and coated with asphalt. In 1978, contaminated soil and vegetation were removed from the area. The area was then herbicided, graded with fresh soil, covered with a clay overburden, and covered with asphalt.

Radiological data collected in 1977 indicated elevated concentrations of Cs-137 (310 $\mathrm{pCi} / \mathrm{gm})$ and $\mathrm{Sr}-90(128,600 \mathrm{pCi} / \mathrm{gm})$ in vegetation. Radiation surveys conducted from August 1990 to April 1995 indicated elevated count and dose rates in the area. Furthermore, the surveys demonstrated that the contaminated area was increasing, presumably from contaminants mobilized by the activity of the vegetation. For this reason, it is planned to remove the vegetation from the site during the present year.

\subsection{HP-52 Outfall}

The HP-52 Outfall is located approximately $300 \mathrm{~m}$ south of Road $E$ at a point $0.8 \mathrm{~km}$ west of the intersection of SRS Roads $E$ and 4 . The Outfall receives storm water sewer drainage from the H-Area Tank Farm and powerhouse cooling water effluent.

The following site description is taken from the Removal Site Evaluation Report for HP52 Outfall (WSRC-RP-95-1536). The area is composed of two small areas in which contaminated soil have been buried and a section of stream, approximately $120 \mathrm{~m}$ long, originating at the storm sewer discharge from the H-Area Tank Farm and joining Four Mile Branch at its lower end. The stream banks are heavily overgrown with brush and small trees. The species composition reflects the disturbances in construction of the sewer/outfall system and the moist habitat of the stream banks. Willows and other early successional wetland species make up most of the tree canopy.

The storm sewer outfall became contaminated in May, 1967 and again, in February, 1969. In 1967, overflow of high level waste to the ground and nearby sewer occurred during transfer of waste in the H-Area Tank Farm. In 1969, waste reached the storm sewer following a rupture in a waste transfer line. Most of the high level waste (primary 
radionuclide Cs-137) from the 1967 incident seeped into the soil, approximately 1200 Ci of contamination was removed to the SRS Burial Ground. The 1967 incident resulted in a much smaller release in which $0.5 \mathrm{Ci}$ of $\mathrm{Cs}-137$ was moved to the burial ground.

A Savannah River Forest Service inventory of the trees at this waste site estimates a mass of approximately $115,000 \mathrm{lbs}$ (green weight) of wood. Radionuclide analysis of the trees is not available at the present time.

\subsection{TNX Burying Ground (643-5G), Old TNX Seepage Basin and New TNX Seepage Basin (904-076G, -102G)}

The TNX Area is located in the southwestern portion of the Savannah River Site. It is located approximately one quarter of a mile from the Savannah River, between Upper Three Runs Creek and Four Mile Branch Creek. The area is at an elevation of 46 meters above mean sea level. The TNX Area is the pilot scale testing and evaluation facility for the Savannah River Technology Center. The facility was used for chemical processes research and development activities in support of the separations areas, the fuel fabrication facilities and the Defense Waste Processing Facilities. Waste water generated by these activities was discharged to seepage basins.

Contaminated areas include the Old TNX Seepage Basin, the New TNX Seepage Basin, and the TNX Burying Ground. Some contamination, primarily chlorinated solvent, is known to have been released from the process sewer receiving liquids from an equipment degreasing area. Only two of these areas are known to have significant releases of radionuclides. In 1953, an experimental evaporator containing approximately $590 \mathrm{~kg}$ of uranyl nitrate exploded. The contaminated evaporator, its housing, associated timber, steel work, and other material was buried at three locations (TNX Burying Ground). The trenches were rediscovered in the 1980's when waste was encountered during construction activities. Much of the activity was moved to the SRS Solid Waste Disposal Facility at this time. Contamination remains in areas beneath buildings or near areas not excavated because of buried utilities. No known cases of contaminated vegetation are associated with this area.

The Old TNX Seepage Basin was an unlined excavation on the west side of the TNX Area. The basin was built in 1958 and received waste water through the spring of 1980. Water entered the basin through an underground pipe. The basins overflow passed over a weir into the Savannah River Swamp. The swamp contains a stand of timber which has been demonstrated to contain elevated levels of heavy metals. Analysis has not been done for radionuclides. It has been estimated that approximately $0.2,0.03$, and 0.2 curies of the isotopes Thorium-232, Uranium-235, and Uranium-238, respectively, entered the swamp area from overflow of the basin. No measurements of radioactivity or radioisotope inventory exist for the swamp forest. 
2.7 R-Area Reactor Seepage Basins (904-57G, -58G, -59G, -60G, -103G, and 104G) and Overflow Basin (108-4R),

The R-Reactor Seepage Basins consist of six unlined basins excavated and operated between 1957 and 1964. The basins are located north of the R-Reactor building. They received low-level purge water from the reactor disassembly basin. Primary radionuclides in the purge water were tritium, strontium-90 and cesium-137. The basins received approximately 4.8 million gallons of purge water from routine and nonroutine reactor operations.

Non-routine operations were primarily the result of a calorimetric test failure in 1957 which resulted in an estimated release of 200 curies of strontium-90, 1000 curies of cesium-137, and 1500 curies of other radionuclides (primarily beta emitters with halflives less than 3 years).

In the early 1960's, all basins were backfilled with kaolin clay and sprayed with a thin layer of asphalt emulsion to control vegetation. Clay dikes were constructed around basin 1 and the northwest of basin 3 to contain lateral movement of radionuclides and reduce infiltration in the basin area.

The asphalt covering on the basins cracked and vegetation slowly invaded the area. However, in the 1980's and again recently, the vegetation (which included small trees) was cut, herbicided, and the surface of the clay sprayed with asphalt. This has kept the size of the trees growing on the site small. Soil, groundwater, and vegetation surveys have been conducted at the waste site since 1957. The vegetation surveys indicate contamination in only very limited areas where the vegetation roots have reached the contamination in the basins. The volume of wood associated with these areas has not been measured but, because of the vegetation control measures taken thoughout the existence of the basins, the volume is not thought to be very large. 


\subsection{POTENTIAL APPLICABLE PROCESSES}

Since there are no standard methods for dealing with radiologically contaminated vegetation, we have searched the literature in an attempt to develop a matrix that includes, to the best of our knowledge, all relevant processes that should be considered in the development of a single process or group of processes suitable for the sites at SRS. We assume that the best alternative(s) selected for SRS will have widespread utility in numerous sites, world-wide, where radiologically contaminated vegetation poses a problem. The alternatives include physical, chemical and biological processes. Physical processes include such things as the use of heat and pressure, as well as chipping and grouting. Chemical processes include bleaching, acid digestion and the use of ion exchange resins. Biological processes include phytoremediation as well as natural and amended decay processes including composting. An overall design matrix depicting the various treatment alternatives as determined by the literature review is shown in Table 9. The next step in the project will be to select the most promising alternative(s) via a work plan for future study. This selection process will be done on the basis of cost, risk, and need. Additional studies will be conducted to identify costs, as well as risks vs. benefits for the most feasible options. Other factors to be considered in the selection process will include regulatory milestones (drivers) and potential processes that are already being used in other applications on site (e.g. vitrification, incineration, the $\mathrm{H}$-Area effluent treatment facility, etc.). 


\section{Table 9. Options for Dealing with Contaminated Vegetation}

1. Allow vegetation to continue growing (continued phytoremediation soil)..................2

1. Stop vegetation from growing............................................................................

2. Provide transparent physical containment to prevent potential transport of radionuclides

2. Provide monitoring to assess potential transport of radionuclides

2. Enhance phytoremediation activities by biostimulation and/or bioaugmentation

3. Apply herbicide to kill vegetation but don't harvest

3. Harvest killed vegetation (before or after herbicide application) ............................5

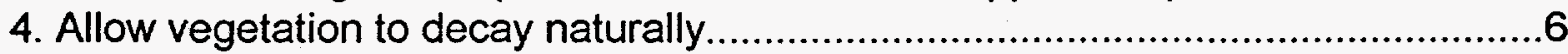

4. Enhance vegetation decay by bioaugmentation and/or biostimulation.................7

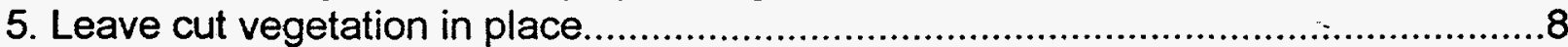

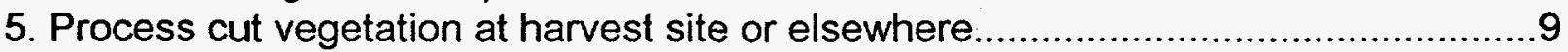

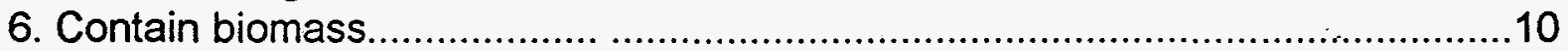

6. Don't contain biomass - monitor for radionuclide mobility

7. Add fertilizer

7. Add biological agents

8. Allow vegetation to decay naturally

8. Enhance vegetation decay by bioaugmentation and/or biostimulation

9. Chip or otherwise comminute 11

9. Burn.

10. Provide physical containment to prevent potential transport of radionuclides

10. Bury harvested material - seal with grout

11. Process comminuted vegetation for volume reduction by physical and/or chemical treatment.

11. Process comminuted vegetation for volume reduction by biological treatment.......14

12. Open air burning - monitoring in an attempt to comply with regulations

12. Transport to Incineration equipped with an offgas containment/collection system

13. Reduce volume by combustion

13. Reduce volume by chemical digestion (e.g. chlorine and/or acid) ....................16

14. Allow natural decay.

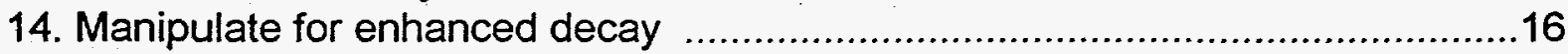

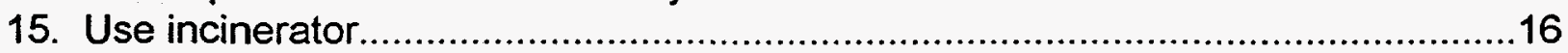

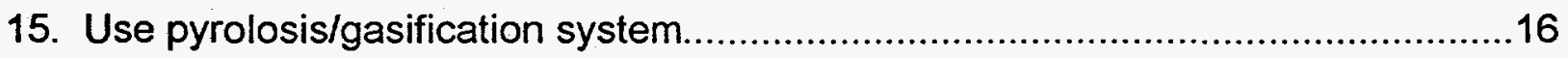

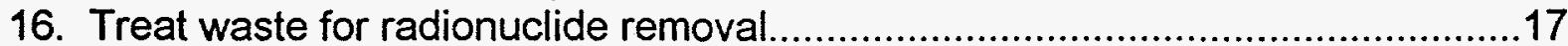

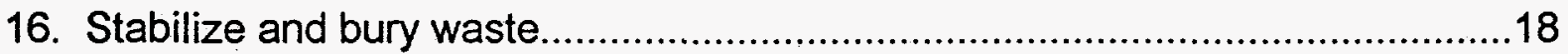

17. Remove radionuclides by use of ion exchange resins

17. Remove radionuclides by using crown ethers or chelators (i.e. EDTA)

18. Encapsulate in cement and bury

18. Encapsulate in glass (vitrification) 


\subsection{General Overview of Options}

The first issue to address is the current value versus risk of the ongoing phytoremediation process at the subject waste sites. Clearly, the vegetation is removing radionuclides from the underlying soil. Having control of this process, i.e. optimizing uptake and managing disposal is of considerable value. There is an extensive literature on phytoremediation in general (Cunningham and Ow, 1996; Hinchman and Negri, 1994) and some articles on the use of phytoremediation for the removal of radionuclides. For example, Landeen and Mitchell (1986) studied the uptake of radionuclides by trees around a radwaste pond at the DOE Hanford Washington site and concluded that $\mathrm{Sr}-90$ was more readily taken up by the trees than Cs-137. However, if the growing vegetation causes too great of a threat to the environment by allowing the dispersal of radionuclides that might otherwise be stabilized in the soil, harvesting and halting the phytoremediation process might be the best option. Thus, the following discussion in this report is focused on harvesting and processing the contaminated vegetation at the waste sites, rather than using plant material for continued sequestering of contaminants from the soil. Numerous choices are involved. They include a variety of physical, chemical and biological processes aimed at reducing the volume of the killed vegetation and stabilizing or removing the associated radionuclides.

\subsection{COMMINUTION}

Comminuting (reducing the particle size of harvested vegetation) is an early step in numerous possible physical, chemical or biological volume reduction schemes. Comminution can be accomplished by several mechanisms such as the following taken from Smith and Boley (1993).

A. Splintering ---wood fed between two rotating serrated rollers that turn at different speeds to produce splinters

B. Excising---debarking to remove bark from tree stems preparatory to further processing

C. Chipping and flaking---solid wood fed rapidly into rotating knives. Chipping generally used as an intermediate process to reduce

wood

for fiber reduction. Flaking is designed for large, consistently-sized wood pieces

D. Shearing--- Shears consist of two or more hydraulically driven counterrotating rotors with heavy, intermeshing knives

E. Hamermilling--- Swinging hammers are mounted radially on a rotating shaft. Material is retained in the chamber until it is small enough to pass through screens of selected size. 
F. Shredding--- auger shredders use hydraulically driven, slow rotating, double -opposed augers to crush and shred materials in an open rectangular chamber - used for shredding telephone poles and railroad ties.

\subsection{Volume Reduction by Physical and/or Chemical Treatments}

Volume reduction can be accomplished by combustion of the vegetation, mechanical pulping and washing, chemical pulping, and complete chemical hydrolysis of the vegetation. All of these processes produce waste streams that must be stabilized and disposed of in some manner. The success of a process depends on its ability to stabilize the waste in a form suitable for disposal in a manner that is both economically efficient and environmentally acceptable.

\subsubsection{Combustion}

The simplest type of combustion is open air burning of the vegetation. This process greatly reduces the volume of waste. However, it has several drawbacks. Some of the contaminants in the waste may be volatile or be incorporated in the smoke from the fire. The contaminants in the smoke are essentially treated by dilution. This is often unacceptable to regulatory agencies even when the chance of health consequences are quite small. The ash left on the ground is not stabilized unless it is treated by grouting with the soil.

Incineration can provide the same, or better volume reduction while controlling stack emissions and was the preferred alternative in an earlier investigation of disposal of contaminated vegetation at SRS (Malik, et al. 1995). Typically, an incineration system will require the vegetation to enter the system as chips or similar ground particles. The off gas system will be scrubbed to collect vapors and reactive gases and filtered to remove suspended particles. Incineration systems produce a solid "bottom" ash, a solid filter and fly ash, and a quench/scrubber liquid waste solution. Each one of these waste must undergo further treatment.

Pyrolysis/gasification systems have been developed to try to overcome the need for a complex off gas system. The theory is that the gentler combustion will limit the stack emissions to gases that contain no solids and can be flared to get rid of organic wastes. One such system uses a reverse burn where the combustion takes place at the top of a column and the gases are filtered by flowing through the unburned material and the char falling from the combustion volume at the top of the column. The char collection volume is kept below the burning front of the column and will remove low volatility vapors, such as $\mathrm{Cs}$, from the gas stream. The highly volatile gases are burned as they leave the column. The process leaves only the contaminated char and ash for 
disposal. Solids from incineration and pyrolysis systems can be stabilized in cement or by vitrification.

\subsubsection{Chemical Digestion}

Many inorganic contaminants in vegetation, such as $\mathrm{Sr}$ and $\mathrm{Cs}$ salts, are dissolved or absorbed loosely on the surface of cell constituents. Some are more tightly bound or incorporated in the chemical constituents. In either case, the cell walls and membranes are barriers to removal of the contaminants. The cell wall structure can be disrupted by high pressure steam or mechanical pulping. This can lead to the mobilization of some of the contaminants which can then move into solution and be removed from the pulp. Although the contaminant levels are decreased there is little reduction in volume and the resulting waste streams from this type of process are a liquid stream containing most of the inorganic contaminants and a solid waste stream which will still retain some of the contaminants.

More thorough destruction of the cell walls and membranes will release greater amounts of contaminants. In addition, chemical pulping, such as used in the paper industry will delignify the wood leading to about a $50 \%$ reduction in solid waste. The liquid stream from this kind of process will contain most of the inorganic salts, as well as organic extractives and the products of lignin degradation.

If delignification is followed by strong oxidation, some of the hemi-cellulose will degrade to soluble carbohydrates and if the oxidation is strong enough some of the organic materials will oxidize to water and carbon dioxide. Strong nitric acid or sulfuric acid treatments can lead to solid waste volume reduction greater than $80 \%$. A mixture of nitric and phosphoric acid can lead to a solid waste reduction in excess of $95 \%$. This "wet ashing" process also results in a liquid stream which, after distillation of the nitric acid, contains primarily the dissolved salts of the inorganic constituents of the wood.

Another option, after delignification, is to digest the cellulose with cellulase enzymes. This degrades the cellulose into simple sugars. Processes of this type have been used to produce alcohol from vegetable wastes. Another possibility is to piggyback on a wet chemical oxidation technology being developed by SRTC as another task (TTP-SR- 16LF-51B) in the same OTD funded project as our study. This process uses a combination of nitric acid and phosphoric acid. The phosphoric acid allows the nitric acid to be retained in solution well above the normal boiling point). The reaction converts organics to carbon dioxide and water, and generates NOx vapors that can be recycled using air and water. The oxidation is complete in one to three hours. Promising results have been observed for the oxidation of organic compounds including cellulose. (Pierce and Smith, 1995).

None of the physical or chemical biomass treatments are without problems. They all produce waste streams that must be disposed of by safe and environmentally accepted methods. The complexity of many of the processes will drive up their cost. However, it may be possible to combine these methods with other waste disposal 
activities. The ash from combustion could be processed in the existing vitrification or saltstone facilities. The reverse burn gasification system could be used to dispose of other organic wastes. The liquid effluents from the chemical degradation processes could be decontaminated in one of the existing Effluent Treatment Facilities or encapsulated in the saltstone.

\subsection{Volume Reduction by Biological Methods}

\subsubsection{Natural Decay of Vegetation}

Decay rates for forest detritus like leaf litter, woody litter (e.g. twigs and branches) and course woody debris (CWD = material $>7.5 \mathrm{~cm}$ diam.) can be expressed by a parameter $k$, which is an expression of the fraction of the stored quantity (i.e. amount of organic debris) that is lost per unit time, or the fractional loss rate (Olson 1963). From Olson(1963), the fractional loss rate is determined from measurements of the amount of material that has accumulated on the forest floor (X), expressed, for example, as oven dry weight of organic carbon per $\mathrm{m}^{2}$ of ground surface or density $\left(\mathrm{g} / \mathrm{cm}^{3}\right)$, and the rate of addition of new material to the forest floor or density changes (L) expressed in identical terms, by the following equation:

\section{(1) $d X / d t=L-k X$}

This model assumes: (a) no transformation of organic detritus to more or less decomposable forms; (b) a constant rate of decomposability; and (c) a uniform distribution of detrital constituents along the decomposability continuum (Carpenter 1981). Under steady state conditions, where the rate of decay equals the rate of addition, (i.e. where $\mathrm{dX} / \mathrm{dt}=0$ ):

(2) $k=L / X s s$

$k$ can be estimated by the ratio of input to steady-state total. Under conditions where there is no input to the system (i.e. where $L=0$ ), a situation that is analogous to felling existing vegetation and preventing any regrowth, decay rates are determine by rearranging equation (1) to express losses as a fraction of the residue $X$ currently remaining:

\section{(3) $d X X X=-k d t$}

which gives the equation:

$$
\text { (4) } X / X O=e-k t
$$

This model implies a constant negative slope $-k$, on a semi-log graph of the amount remaining from a initial quantity $\mathrm{XO}$ at $\mathrm{t}=0$. 
Comparison of decay rates from different reports is difficult because different methods (e.g. density change vs. mass loss) are often used to determine them. $k$ values calculated by dividing input by accumulation are larger than those calculated from density change alone (Sollins 1982). This is because decay rates calculated on the basis of density change only account for loss of $\mathrm{C}, \mathrm{H}$, and $\mathrm{O}$ via microbial respiration plus small amounts of other elements leached from wood, whereas those based on weight loss include fragmentation-the breaking up of CWD into smaller particles (Sollins 1982). Decay rates, for CWD from western softwoods, based on density change generally range from 0.006 to $0.012 \mathrm{yr}-1$, while those that include fragmentation generally range from 0.028 to $0.031 \mathrm{yr}-1$ (Sollins 1982). The importance of fragmentation to decay was demonstrated in a study of log decay of subalpine balsam fir (Lambert et al. 1980). Based on density change (i.e. respiration) alone, $k$ was $0.012 \mathrm{yr}-1$; based on both density and volume change, $k$ was $0.030 \mathrm{yr}-1$. The $0.018 y r-1$ difference is an estimate of fragmentation, which contributed more weight loss at the subalpine site, than did respiration. To include both processes the decay rate constant can be divided into two parts $k=k m+k f$, where $k$ is the overall decay constant, $\mathrm{km}$ is the rate constant for mineralization losses due to respiration and leaching, and $\mathrm{kf}$ is the decay rate constant for losses due to fragmentation (Harmon et al. 1986).

The decay rate of plant biomass (i.e. litter and wood) is based on the outcome of a complex series of interactions between resource quality, microclimate and organisms and is controlled largely by the following four factors (Tenney and Waksman 1929):

(1) the chemical composition of the plant material

$(2)$ the presence of sufficient nitrogen $(\mathrm{N})$ to enable the decomposing microorganisms to carry out decomposition

(3) the nature of the microorganisms involved in the decomposition process, and

(4) the environmental conditions under which decomposition is carried out.

The chemical composition of the plant material depends on the nature and age of the plants and the conditions of their nutrition. Lignins are aromatic substances resulting from the polymerization of phenylpropanoid subunits to form very complex molecules. They are usually present in larger amounts in softwoods (25-35\%) than in temperate hardwoods(18-25\%) (Rayner and Boddy 1988). Lignin has been found to be the least decomposable biochemical constituent of higher plant litter (Suberkropp et al. 1976, Godshalk and Wetzel 1978a,b). It has been shown to decay more slowly than cellulose and hemicelluloses (Crawford 1981) which leads to an increase in the lignin-to cellulose ratio as decay proceeds, and significant negative correlations between decay rates and lignin contents have been reported (Fogel and Cromack 1977, Meentmeyer 1978). The more rapid decay rates of leaf litter in comparison to wood have been attributed, in part, to the lower lignin content of the leaf litter (Cromack 1973). For example, decay rates of leaf litter in the southern Appalachian region(e.g. $12 \%$ to $68 \%$ $\mathrm{yr}-1)$ are much faster than those of standing boles in the Southern Appalachian 
mountains (e.g. 3.1 to $11 \%$ yr-1) (Harmon 1982). Differences in decay rates have also been observed among various log components (e.g. outer and inner bark, sapwood and heartwood). The inner bark of oak (Quercus spp.) logs decayed more rapidly ( $k=$ $0.59)$ than either the heartwood $(k=0.31)$ or the sapwood $(k=0.2)$ (Schowalter 1992). It is generally thought that litter and wood from hardwoods decays faster then material from conifers. However, under identical climatic conditions, decay rates of standing boles of several hardwood species (Cornus florida, $\mathrm{k}=0.05$ and Oxydendrun arboreum, $k=0.05$ ) were comparable to those of several softwood species (e.g. Pinus virginiana, $\mathrm{k}=0.04$ and Tsuga canadensis, $\mathrm{k}=0.04$ ) (Harmon 1982). Several of the hardwood species including Nyssa sylvatica and Quercus prinus had significantly greater decay rates of 0.20 and 0.18 , respectively. Decay constants $(k)$ for deciduous and coniferous forests range between 0.004 to $0.5 \mathrm{yr}-1$ (Harmon et al. 1986, Mattson et al. 1987). Values of $k$ for litter decay in pine forests of the southeastern U. S. vary around 0.25 (Olson 1963). Decay rates for woody material would be expected to be significantly slower. Decay rate is also related to the size of material. As indicated above, decay rates for fine materials like leaf litter are very fast. In general, decay rate decreases until a piece is approximately $20 \mathrm{~cm}$ in diameter and then remains relatively constant with further increase in size (unpublished data) .

There must be sufficient nitrogen $(\mathrm{N})$, and other nutrients, to enable microorganisms to carry out decomposition The addition of extra $\mathrm{N}$ to organic materials poor in $\mathrm{N}$ increases their rate of decomposition (Parnas 1975). The rate of wood-residue (from Pinus ponderosa Laws) amendments in bentonite mine spoils was significantly enhanced by the addition of $N$ (Schuman and Belden 1991). The rate of decomposition was significantly enhanced at $\mathrm{C} / \mathrm{N}$ ratios $>137: 1$.

The rate and type of decay is greatly influenced by the organisms involved in the decay process. It is through these organisms that the influence of temperature, moisture, aeration, substrate quality, and size, on decay rates is expressed (Harmon et al. 1986). A wide range of microorganisms and fauna (i.e. invertebrates) from diverse taxonomic categories are omnipresent in soil profiles and interact to rapidly colonize and destroy wood (i.e. CWD) and litter. Soil fauna facilitate microbial growth and degradation of plant material by: 1) Shredding plant parts in forest litter and by burrowing into CWD. These activities expose encapsulated nutrients to microbial attack; 2) Moving either the plant material or the microbial innocula externally or through their guts, in a continual mixing of the soil; and 3) insuring a succession of microbes with different enzymatic capabilities to process plant tissues by feeding directly on decomposer fungi or on fungivorous taxa. The use of "functional" groups has been considered useful in characterizing soil microflora. Thus, Clubbe (1980) recognized six groups based on his own findings and from other published studies. They are: 1) bacteria; 2) primary molds; 3) stain fungi; 4) soft rot fungi; 5) secondary molds; and 6) basidiomycetous fungi (i.e. white-rots and brown-rots). Groups 1-5 are significant components of the microflora of the organic layers of forest soils. Their effects are primarily involved in the mineralization of $\mathrm{P}, \mathrm{N}, \mathrm{K}$, and $\mathrm{Ca}$, primarily through superficial activity in wood. Although some soft rots and bacteria can cause significant reductions in strength loss 
and affect other wood properties, it is the white- and brown-rot basidiomycetes that are primarily responsible for wood decay and volume reduction (Frankland et al. 1982). In North America, there are approximately 1700 species of basidiomycetous wood-rotting fungi. Of this 1700 , only about $6 \%$ cause brown-rots while the remainder occur as white-rotters. Distribution and substratum relationships are also of interest here. Forest ecosystems of North America may be referred to as brown- or white-rot ecosystems. Brown-rot fungi are more prevalent in conifer ecosystems; whereas, white-rot fungi are more prevalent in deciduous or hardwood ecosystems. The reasons for these preferences may be due to differing climatic conditions, lignin and extractive differences between hardwoods and softwoods and wood pH. The end result of the effects of the activities of wood decay is the nature of the "final stages" of decomposition. White-rot fungi are the only type of wood rotting fungi that can attack all the wood components, the lignin as well as the polysaccharides (Eriksson, 1988). White-rotted wood is physically dispersed and becomes an unrecognizable component of the soil carbon resource. In contrast, brown-rotted wood is $60-70 \%$ lignin, a very recalcitrant polymer in terms of enzymatic degradation. Thus, a lignin residue (ca. $20-25 \%$ of original weight) of brown-rotted wood has the potential of remaining on site with much of its physical integrity intact.

The environmental conditions under which decomposition is carried out (i.e. aeration, moisture supply, and temperature) also have a substantial effect on the decomposition rate of forest litter. This has been demonstrated in studies by Mikola (1960), Bunnell et al. 1977., Fox and Van Cleve (1983), and Meentmeyer and Berg (1986). In general, decay rates increase with increasing temperature and moisture up to optimum values that favor the growth and activity of decomposer organisms. Decay rates of Quercus prinus woody liter (i.e. twigs and branches) ranging between $0-5 \mathrm{~cm}$ in diameter were 2.3 times faster on a clear-cut mesic site $(k=0.1384)$ than on a clear-cut xeric site $(k=$ 0.0594 ) (Abbot and Crossley 1982). The effect of temperature on decay rates was also illustrated in a study in Sweden that reported decay rates in southern Sweden that were 2-4 times faster than in northern Sweden where average temperatures are much lower (Samuelsson et al. 1994). The dramatic effect of both temperature and moisture on litter decay rates in evergreen forests was illustrated by Olson (1963) in a plot of annual liter production $\left(\mathrm{L}=\mathrm{gC} / \mathrm{m}^{2}\right)$ versus steady-state accumulation of forest floor (Xss), for various evergreen species growing under different climatic conditions. In this case $k$ was determined using equation 2 . In the tropics (e.g. Ghana) (Nye 1961), the Congo (Laudelot and Meyer 1954), and for Columbia (Jenny 1950), $k$ values were very high and ranged between 0.875 and 4 . In the temperate southern pine forests (e.g. Pinus palustrus (Heyward and Barnette 1936); Pinus elliotii and mixtures on the southeastern U. S. coastal plain, (Metz 1952, 1954); Pinus echinata and mixtures with Pinus taeda on the South Carolina Piedmont, (McGinnis 1958); and Pinus virginiana in the Appalachian Ridge and Valley province at Oak Ridge, Tennessee), $k$ values were medium to high and ranged between 0.33 and 0.13 . Finally, $k$ values from evergreen litter (Pinus ponderosa and Pinus contorta, (Jenny et al. 1949, Jenny 1950) in the dry climate of the Sierra Nevada mountains in California were low to very low and ranged between 0.06 to $<0.01$. 
Thus, natural decay processes are probably too slow for the waste site closure schedules at the SRS. For example, a remediation option involving the application of a herbicide to kill existing vegetation, letting it decay in place, incorporating the decayed vegetation into the soil, and capping would take about 15 years for the woody vegetation to reach a state at which it could be incorporated into the soil with stable grouting (assuming $k=0.33$ for litter and $95 \%$ decay of litter, Olsen, 1963).

\subsubsection{Enhanced Decay}

The biological decay rate can be enhanced by bioaugmentation (i.e. adding lignocellulose-degrading organisms) and/or biostimulation (i.e. adding nutrients to stimulate the activity of lignocellulose-degrading organisms). For example, the production of lignin and xylan degrading enzymes by white-rot fungi can be greatly influenced by the culture or environmental conditions the organisms are subjected to (Pellinen et al. 1989, Niku-Paavola et al. 1990, Copa-Patino et al. 1993). Conditions have even been defined under which lignin, cellulose and xylan degradation occurs simultaneously by the white-rot fungus Phanerochaete chrysoporium ( Birch 1988 in Copa-Patino et al. 1993). Conditions have also been reported where wood degradation can be further enhanced by combining cellobiose -oxidizing enzymes produced by fungi with other chemicals such as Fe (III) and hydrogen peroxide (Henriksson et al. 1995). In addition to volume reduction, the fungi might also play a role in the decontamination of wood by virtue of their ability to accumulate radionuclides. Numerous radioecological studies have shown that radionuclides, particularly Cs-137 are accumulated by fungi (Bohac et al. 1989). A particular problem with this approach is the separation of the radionuclides from the fungal hyphae.

Another potential biological approach to the remediation effort is to incorporate composting into the remediation scheme. Composting is essentially the deterioration of biodegradable solid organic matter by aerobic microbes to form a stable, humic material. Principal factors influencing the composting process include oxygen, temperature, moisture content and corresponding free air space (Jeris and Reagan 1973a,b), C/N ratio, pH, and particle size of raw materials (de Carvalho et al. (1991). Although these factors change during the composting process, generalized optimal conditions are as follows:

oxygen: $>18 \%$ (deBertoldi et al. 1983)

temperature: $45^{\circ}-55^{\circ}$ (Bagstrum 1977)

moisture content :60-70\% (Campbell et al. 1990)

C/N ratio: $30: 1$ to $50: 1$ (Rao et al.1995), and

$\mathrm{pH}$ : near neutral (Bagstrum 1977).

Wood chips and bark have proven to be a good bulking agent for combining with sewage sludge to provide compost (Frankos et al. 1982, Solbraa et al. 1983, Martin et 
al. 1993). However, the rate of biodeterioration is inversely related to the ratio of Lignin:nitrogen (Melillo et al. 1982). Thus, additional nitrogen is required to speed up the process. The amount of additional nitrogen needed for optimal composting has been shown to be species dependent ( Still et al. 1974). As previously mentioned, the biological degradation of lignin is an enzymatic aerobic transformation restricted to the higher fungi (basidiomycetes). These organisms degrade lignin slowly but the process can be speeded up by composting in a static pile composting system with forced ventilation to maintain mesophilic temperatures and sufficient oxygen (de Bertoldi et al. 1983, Psarianos et al. 1983), or by bioreactor systems (Ashbolt and Line 1982, Viel et al. 1987, Campbell et al.1990,a,b,).

The traditional purpose of composting is to produce a well-stabilized, humified, organic material for use as a soil amendment or mulch. However, composting is also becoming increasingly popular as a means of biodegrading toxic compounds such as pesticides (Fogarty and Tuovinen, 1991) and as a way to reduce volume of waste. Composting has been shown to provide a means of volume reduction up to $50 \%$ and weight losses of 16-38\% (Bagstam, 1977; Chang-Ho, 1977; Ashbolt and Line, 1982 ). Thus, it deserves consideration as a inexpensive volume reduction process for contaminated vegetation.

\subsection{Stabilization or Removal of Radionuclides in Waste Streams and Residue 3.4.1 Mechanical Stabilization of Vegetation}

The simplest way to stabilize the contaminated vegetation is to cut it to the ground, herbiciding to prevent regrowth, and cover the soil surface with an asphalt emulsion. This has been done in several areas of SRS as a temporary means of limiting the transport of contamination by vegetation on severely contaminated areas. The problem with this approach is that it requires continual maintenance and does not provide a permanent closure of the contaminated area.

A more permanent stabilization can be made by encapsulating the vegetation in cement. This can be done at the same time as in situ grouting of the soil if the size of the vegetation is reduced by chipping or grinding the trees and shrubs. Contaminants encapsulated by this method should be isolated for fairly long periods and can be part of a site closure. However, grouting of chips increases rather than reduces the volume of waste.

Further treatment of the liquid waste stream following chemical digestion is needed to produce an acceptable waste from any of the chemical degradation processes. The simplest technique is to evaporate the water leaving the dissolved salts and organic residue in a slurry or dry form. This material can be further stabilized by addition of cement. 


\subsubsection{Radionuclide Removal}

It may be necessary to treat the residue and/or waste from any physical chemical or biological volume reduction scheme for removal of radionuclides. This can be accomplished by the use of ion exchange resins or liquid extraction (i.e. use of crown ethers) processes.

In all of the chemical digestion processes there is a solid waste stream that must also be treated further. In the case of the washing or mild digestions there is a relatively large volume of vegetation fibers that must be disposed of. The simplest solution would be to return the fiber, now of low radionuclide content, to the waste site to be used as a mulch and to finally be incorporated into any soil treatment at the waste site. In the case of wet ashing, the volume of solid waste may be reduced to the point that stabilization in cement or by vitrification may be reasonable options. Stabilization of ion exchange resins may also be done through vitrification, or encapsulation in cement or a metal matrix. 


\subsection{SUMMARY AND CONCLUSIONS}

A comprehensive literature review has clearly revealed that there are no standard procedures for dealing with radiologically contaminated vegetation at SRS or elsewhere. Thus, procedures need to be developed. Factors to be considered in this development should be, in order of importance, safety, cost-effectiveness, and timeliness. This review describes the principal waste sites at SRS in need of remediation and a variety of physical, chemical and biological processes that deserve consideration in developing an appropriate strategy for dealing with the problem. The next step is to systematically reduce the large number of possible alternatives described in this review to a single scenario or small, manageable number of treatment scenarios that can be successively developed from bench to pilot to full-scale treatment systems. 
WSRC-TR-96-0125

\subsection{LITERATURE CITED}

Abbot, D.T. and D.A. Crossley, Jr. 1982. Woody litter decomposition following clearcutting. Ecology 63: 35-42.

Ashbolt, N. J. and M. A. Line. 1982. A bench-scale system to study the composting of organic wastes. J. Environ. Qual. 11: 405-408.

Bagstam, G. 1977. Experiments made in bench scale composters. III. Composting of spruce-bark together with sewage sludge. Vatten. 33: 239-250.

Bransford, J.L., H.W. Bledsoe, R.V. Simmons. 1988. Technical Data Summary, Chemical Characterization of sediments and Groundwater at the Savannah River Laboratory Seepage Basins. DPSTD-84-110, E.I. du Pont de Nemours, Inc., Savannah River Laboratory, Aiken, S.C.

Bunnell, F.L., D.E.N. Tait, P.W. Flanagan, and K. Van Cleve. 1977. Microbial respiration and substrate weight loss. I. Soil Biol. Biochem. 9: 33-40.

Bohac J., D. A. Krivolutskii, and T. B. Antonova. 1989. The role of fungi in the biogenous migration of elements and in the accumulation of radionuclides. Agriculture, Ecosystems and Environment. 28: 31-34.

Campbell, C. D., J. F. Darbyshire, and J. G. Anderson. 1990a. The composting of tree bark in small reactors - Adiabatic and fixed-temperature experiments. Biological Wastes. 31: 175-185.

Campbell, C. D., J. F. Darbyshire, and J. G. Anderson. 1990b. The composting of tree bark in small reactors - Self-heating experiments. Biological Wastes. 31: 145-161.

Carpenter, S. R. 1981. Decay of heterogeneous detritus: A general model. J. Theor. Biol. 89:539-547.

Chang-Ho, Y. 1977. Degradation of wood waste by composting. Proc. Symp. Our Environ. pp. 194-200.

Clubbe, C.P. 1980. The colonization of wood by microorganisms. Ph D. Thesis. University of London.

Copa-Patino, J. L., Y. G. Kim, and P. Broda. 1993. Production and initial characterisation of the xylan-degrading system of Phanerochaete chrysosporium. Appl. Microbiol. Biotechnol. 40: 69-76.

CORR-87-0117, A Characterization Study of the Old F-Area Seepage Basin at the United States Department of Energy's Savannah River Plant. Revised March 1987. 
Crawford, R.L. 1981. "Lignin biodegradation and transformation" Wiley, New York.

Cromack, K. 1973. Litter production and decomposition in a mixed hardwood and white pine watershed at Coweeta Hydrogeological Station, North Carolina. Doctoral Dissertation. University of Georgia, Athens, GA.

Cunningham, S. D. and D.W. Ow. 1996. Promises and prospects of phytoremediation. Plant Physiol. 110: 715-719.

de Bertoldi, M., G. Vallini, and A. Pera. 1983. The biology of composting: A review. Waste Management and Research. 1: 157-176.

de Carvalho, R. A. G., C. G. G. Beca, O. R. Neves, and M. C. S. Pereira. 1991. Composting of pine and eucalyptus barks. Bioresource Technology. 38: 51-63.

DPST-85-692, Environmental Information Document, Old F-Area Seepage Basin, E.I. du Pont de Nemours, Inc., 1985

Eriksson, K..E. 1988. Microbial delignification - basics, potentials and applications. Biochemistry and Genetics of Cellulose Degradation. pp. 285-302.

Fogarty, A. M. and O. H. Tuovinen. 1991. Microbiological degradation of pesticides in yard waste composting. Microbiological Reviews. 55: 225-233.

Fogel, R. and K. Cromack. 1977. Effect of habitat and substrate quality on Douglas fir (Pseudotsuga menziesii) litter decomposition in western Oregon. Can. J. Bot. 55:16321644.

Fox, J.F. and K. Van Cleve. 1983. Relationship between cellulose decomposition, Jenny's $\mathrm{K}$ value, forest-floor nitrogen, and soil temperature in Alaskan taiga forests. Can. J. For. Res. 13: 789-794.

Frankland, J.C., J. N. Heger, and M. J. Swift. 1982. Decomposer basdidiomycetes: their biology and ecology. Brit. Myco. Soc. Symp. 4 Cambridge University Press. 355 pp.

Frankos, N. H. , F. Gouin, L. J. Sikora. 1982. Using woodchips of specific species in composting. Biocycle. 23: 38-40.

Godshalk, G.L. and R.G. Wetzel, 1978a. Decomposition of aquatic angiosperms. II. Particulate components. Aquatic Botany 5: 301-327. 
Godshalk, G.L. and R.G. Wetzel, 1978b. Decomposition of aquatic angiosperms. III. Zostera marina $\mathrm{L}$. and a conceptual model of decomposition. Aquatic Botany 5: 329354.

Harmon, M. E. 1982. Decomposition of standing trees in the Southern Appalachian Mountains. Oecologia 52:214-215.

Harmon, M.E., J.F. Franklin, F.J. Swanson, P. Sollins, S.V. Gregory, J.D. Lattin, N.H. Anderson, S.P. Cline, N.G. Aumen, J.R. Sedell, G.W. Lienkaemper, K. Cromack, Jr., and K.W. Cummins. 1986. Ecology of coarse wood debris in temperate ecosystems. Adv. Ecol. Res. 15: 133-302.

Henriksson, G., P. Ander, B. Pettersson, G. Pettersson. 1995. Cellobiose dehydrogenase (cellobiose oxidase) from Phanerochaete chrysosporium as a wooddegrading enzyme. Studies on cellulose, xylan and synthetic lignin. Appl. Microbiol. Biotechnol. 42:790-796.

Heyward, F. and R.M. Barnette. 1936. Field characteristics and partial chemical analyses of the humus layer of longleaf pine forest soils. Florida Agr. Expt. Sta. Bull. $302,27 \mathrm{pp}$.

Hinchman, R. and C. Negri. 1994. The grass can be greener on the other side of the fence. Argonne National Laboratory. Logos. 12: 8-11.

Jenny, H. 1950. Causes of the high nitrogen and organic matter content of certain tropical forest soils. Soil Science 69: 63-69.

Jenny, H., S.P. Gessel, and F.T. Bingham. 1949. Comparative study of decomposition rates of organic matter in temperate and tropical regions. Soil Sci. 68: 419-432.

Jeris, J. S. and R. W. Regan. 1973a. Controlling environmental parameters for optimum composting. 1. Experimental procedures and temperature. Compost Science. Jan.-Feb., pp. 10-15.

Jeris, J. S. and R. W. Regan. 1973b. Controlling environmental parameters for optimum composting. II. Moisture, free air space and recycle. Compost Science. MarApr., pp. 8-15.

Koch, P. 1972. Utilization of Southern Pines. Agriculture Handbook No. 420, Vol I, U.S.D.A., Superintendent of Documents, Washington, D.C., pp 238, 582.

Lambert, R.L., G.E. Lang, and W.A. Reiners. 1980. Loss of mass and chemical change in decaying boles of a subalpine balsam fir forest. Ecology 61: 1460-1473. 
WSRC-TR-96-0125

Landeen, D. S. and R. M. Mitchell. 1986. Radionuclide uptake by trees at a radwaste pond in Washington state. Health Physics 50: 769-774.

Laudelot, $\mathrm{H}$. and J. Meyer. 1954. Les cycles d'elements minearaux et de matiere organique en foret equatoriale congolaise. Trans 5th Int. Congr. Soil Science 2: 267272.

Malik, N. P. S., G. G. Rucker, and M. G. Looper. 1995. Incineration of low level radioactive vegetation for waste volume reduction. Waste management ' 95 . WSRCMS-94-0431X

Martin, A. M., J. Evans, D. Porter, and T. R. Patel. 1993. Comparative effects of peat and sawdust employed as bulking agents in composting. Resource Technol. 44: 65-69.

Mattson, K.G., W.T. Swank, and J.B. Waide. 1987. Decomposition of woody debris in regenerating, clear-cut forest in the southern Appalachians. Can. J. For. Res. 17: 712721.

McGinnis, J. 1958. Forest litter and humus types of East Tennessee. M. S. Thesis, University of Tennessee.

Meentmeyer, V. 1978. Ecology 59:465.

Meentmeyer, V. and B. Berg. 1986. Regional variation in rate of mass loss of Scots pine needle litter in Swedish pine forests as influenced by climate and litter quality. Scand. J. For. Res. 1: 167-180.

Melillo, J. M., J. D. Aber, and J. F. Muratore. 1982. Nitrogen and lignin control of hardwood leaf litter decomposition dynamics. Ecology 63: 621-626.

Metz, L.J. 1952. Weight and nitrogen and calcium content of the annual litter fall of forests in the South Carolina Piedmont. Soil Sci. Soc. Am. Proc. 16:38-41.

Metz, L.J. 1954. Forest floor in the Piedmont Region of South Carolina. Soil Sci. Soc. Am. Proc. 18: 335-338.

Metz, L.J. and C.G. Wells. 1965. Weight and Nutrient Content of the Aboveground Parts of Some Loblolly Pines. USDA Forest Service Res. Pap. SE-17, Southeastern Forest Exp. Sta., Asheville, N.C. , 20 p.

Mikola, P. 1960. Comparative experiment on decomposition rates of forest litter in southern and northern Finland. Oikos 11: 161-166.

Monk, C.D. 1966. Root-shoot dry weights in loblolly pine. Bot. Gaz. 127: 246-248. 
Murphy C.E. Jr. 1994. Vegetation Concentration and Inventory of Metals and Radionuclides in the Old F-Area Seepage Basin, 904-49G (U). WSRC-TR-94-0361, Westinghouse Savannah River Company, Savannah River Site, Aiken, S.C. 15 p.

Murray, C. M., J. L. Thompson, and J. S. Ireland. 1991. Process control improvements at composting sites. Biocycle 32: 54-58.

Niku-Paavola, M. -L., E. Karhunen, A. Kantelinen, L. Viikari, T. Lundell, and A. Hatakka, 1990. The effect of culture conditions on the production of lignin modifying enzymes by the white-rot fungus Phlebia radiata. Journal of Biotechnology 13: 211-221.

Nye, P.H. 1961. Organic matter and nutrient cycles under moist tropical forest. Plant and Soil 13: 333-346.

Olson, J.S. 1963. Energy storage and the balance of producers and decomposers in ecological systems. Ecology 44: 322-331.

Parnas, H. 1975. Model for decomposition of organic materials by microorganisms. Soil Biol. Biochem. 7: 161-169.

Pellinen, J., J. Abuhasan, T. W. Joyce, and H. -M. Chang. 1989. Biological delignification of pulp by Phanerochaete chrysosporium. J. Biotechnol. 10: 161-170.

Pierce, R. A. and J. R. Smith. 1995. Nitric-phosphoric acid oxidation of organic waste materials (U). WSRC-MS-95-0080. Westinghouse Savannah River Company, Savannah River Site, Aiken, SC, 8p.

Psarianos K. M., S. T. MacGregor, F. C. Miller, and M. S. Finstein. 1983. Design of composting ventilation system for uniform air distribution. Biocycle 24: 27-31.

Rao, N., H. E. Grethlein, and C. A. Reddy. 1995. Effect of C/N ratio and moisture content on the composting of poplar wood. Biotechnology Letters 17: 889-892.

Rayner, A.D.M. and L. Boddy. 1988. Fungal decomposition of wood. Its biology and ecology. John Wiley \& Sons. New York. 587 p.

Samuelsson, J., L. Gustafsson, and T. Ingelog. 1994. Dying and dead trees: a review of their importance to biodiversity. Swedish Threatened Species Unit. Uppsala, Sweden.

Schowalter, T.D. 1992. Heterogenity of decomposition and nutrient dynamics of oak (Quercus) logs during the first 2 years of decomposition. Can. J. For. Res. 22: 161166. 
Schuman, G. E. and S. E. Belden. 1991. Decomposition of wood-residue amendments in revegetated bentonite mine spoils. Soil Sci. Soc. Am. J. 55:76-80.

Solbraa, K., M. D. Sant, A. R. Selmer-Olsen, and H. R. Gislerod. 1983. Composting soft and hardwood barks. Biocycle 24: 44-59.

Sollins, P. 1982. Input and decay of coarse woody debris in coniferous stands in western Oregon and Washington. Can. J. For. Res. 12: 18-28.

Smith, M. and G. Boley. 1993. Engineering and economic analysis of processing used wood pallets, etc. to fuel. USDA Forest Service, Forest Products Laboratory Report NTIS \# 53-5680-3-440.

Still, S. M., M. A. Dirr, and J. B. Gartner. 1974. Effect of nitrogen and composting on decomposition of barks from four hardwood species. Forest Product J. 24: 54-56.

Suberkropp, K., Godshalk, G. L., and M. J. Klug. 1976. Ecology 57:720.

Tenney, F. G. and S. A. Waksman. 1929. Composition of natural organic materials and their decomposition in the soil. IV. The nature and rapidity of decomposition of the various organic complexes in different plant materials under aerobic conditions. Soil Science 28:55-X.

Viel, M., D. Sayag, A. Peyre, and L. Andre. 1987. Optimization of in-vessel cocomposting through heat recovery. Biological Wastes 20: 167-185.

Wahlenberg, W.G. 1960. Loblolly Pine. The School of Forestry, Duke University, Durham, N.C. 270p.

WSRC-RP-95-1534. Removal Site Evaluation Report for HP-52 Outfall. Westinghouse Savannah River Company, Savannah River Site, Aiken, SC 29808, August 1995.

WSRC-RP-95-1536. Removal Site Evaluation Report for Warner's Pond. Westinghouse Savannah River Company, Savannah River Site, Aiken, SC 29808, August 1995. 


\subsection{Bibliography}

Abbot, D.T. and D.A. Crossley, Jr. 1982. Woody litter decomposition following clearcutting. Ecology 63: 35-42.

Abe, K. and T. Ohdaira. 1985. A process for treatment of malodorous gas from compost. Akushu no Kenkyu 14: 36-39.

Alestalo, A. and O. Koistinen. 1975. On the possibilities of composting bark and where this compost can be used. ISWA Inf. Bull. 17: 13-17.

Ander, P. and K.-E. Eriksson, 1978. Lignin degradation and utilization by microorganisms. Prog. Ind. Microbiol. 14: 1-58.

Ashbolt, N. J. and M. A. Line. 1982. A bench-scale system to study the composting of organic wastes. J. Environ. Qual. 11: 405-408.

Bagstam, G. 1977. Experiments made in bench scale composters. III. Composting of spruce-bark together with sewage sludge. Vatten. 33: 239-250.

Bagstam. G. 1979. Population changes in microorganisms during composting of spruce-bark: II. Mesophilic and thermophilic microorganisms during controlled composting. European J. Appl. Microbiol. Biotechnol. 6: 279-288.

Benedict, A. H., E. Epstein, and J. N. English. 1986. Municipal sludge composting technology evaluation. Journal WPFC. 58: 279-289.

Beukema, K. J., S. Bruin, and J. Schenk. 1982. Heat and mass transfer during cooling and storage of agricultural products. Chem. Eng. Sci. 37: 291-298.

Bransford, J.L., H.W. Bledsoe, R.V. Simmons. 1988. Technical Data Summary, Chemical Characterization of sediments and Groundwater at the Savannah River Laboratory Seepage Basins. DPSTD-84-110, Rev. 1. E.I. du Pont de Nemours, Inc., Savannah River Laboratory, Aiken, S.C.

Bohac J., D. A. Krivolutskii, and T. B. Antonova. 1989. The role of fungi in the biogenous migration of elements and in the accumulation of radionuclides. Agriculture, Ecosystems and Environment 28: 31-34.

Bunnell, F.L., D.E.N. Tait, P.W. Flanagan, and K. Van Cleve. 1977. Microbial respiration and substrate weight loss. I. Soil Biol. Biochem. 9: 33-40.

Cady, et al. 1993: Mixed waste treatment by reverse-burn basification. Chemosphere, 27: $779-793$. 
Campbell, C. D., J. F. Darbyshire, and J. G. Anderson. 1990a. The composting of tree bark in small reactors - Adiabatic and fixed-temperature experiments. Biological Wastes 31: 175-185.

Campbell, C. D., J. F. Darbyshire, and J. G. Anderson. 1990b. The composting of tree bark in small reactors - Self-heating experiments. Biological Wastes 31: 145-161.

Caple, C. 1994. Reburial of waterlogged wood, the problems and potential of this conservation technique. International Biodeterioration \& Biodegradation. pp. 61-72.

Cappaert, I., O. Verdonck, and M. De Boodt. 1975. Composting of hardwood bark. Compost Science 16: 12-15.

Carpenter, S. R. 1981. Decay of heterogeneous detritus: A general model. J. Theor. Biol. 89: 539-547.

Chang-Ho, Y. 1977. Degradation of wood waste by composting. Proc. Symp. Our Environ. pp. 194-200.

Clubbe, C.P. 1980. The colonization of wood by microorganisms. Ph D. Thesis. University of London.

Composting and Recycling Municipal Solid Waste. Composting. pp. 121-174.

Copa-Patino, J. L., Y. G. Kim, and P. Broda. 1993. Production and initial characterisation of the xylan-degrading system of Phanerochaete chrysosporium. Appl. Microbiol. Biotechnol. 40: 69-76.

Coroneous, A.C., P.A. Taylor et al. 1994. Bench-scale treatability studies from simulated incinerator scrubber blowdown containing radioactive cesium and strontium ORNLTTM-12823.

CORR-87-0117, A Characterization Study of the Old F-Area Seepage Basin at the United States Department of Energy's Savannah River Plant. Revised March 1987.

Crawford, R.L. 1981. "Lignin biodegradation and transformation" Wiley, New York.

Cromack, K. 1973. Litter production and decomposition in a mixed hardwood and white pine watershed at Coweeta Hydrogeological Station, North Carolina Doctoral Dissertation. University of Georgia, Athens, Ga.

Cummings, S. P. and C. S. Stewart. 1994. Newspaper as a substrate for cellulolytic landfill bacteria. Journal of Applied Bacteriology 76: 196-202. 
Cunningham, S. D. and D.W. Ow. 1996. Promises and prospects of phytoremediation. Plant Physiol. 110: 715-719.

Darbyshire, J. F., M. S. Davidson, G. J. Gaskin, and C. D. Campbell. 1989. Forced aeration composting of coniferous bark. Biological Wastes 30: 275-287.

Davis, C. L., C. J. Donkin, S. A. Hinch, and P. Germishuizen. 1992. The microbiology of pine bark composting: An electron-microscope and physiological study.

Bioresource Technology 40: 195-204.

Davis, C. L., S. A. Hinch, C. J. Donkin, and P. J. Germishuizen. 1992. Changes in microbial population numbers during the composting of pine bark. Bioresource Technology 39: 85-92.

de Bertoldi, M., G. Vallini, and A. Pera. 1983. The biology of composting: A review. Waste Management and Research 1: 157-176.

de Carvalho, R. A. G., C. G. G. Beca, O. R. Neves, and M. C. S. Pereira. 1991. Composting of pine and eucalyptus barks. Bioresource Technology 38: 51-63.

Dillon, A.P. 1981. Hazardous Waste Incineration Engineering. Noyes Data Corporation. New Jersey.

DPST-85-692, Environmental Information Document, Old F-Area Seepage Basin, E.I. du Pont de Nemours, Inc., 1985.

Dushenkov, V, P. B. A. N. Kumar, H. Motto, and I. Raskin. 1995. Rhizofiltration: The use of plants to remove heavy metals from aqueous streams. Environmental Science and Technology 29: 1239.

Ejechi, B. O. and C. O. Obuekwe. 1994. The effect of mixed cultures of some microfungi and basidiomycetes on the decay of three tropical timbers. International Biodeterioration and Biodegradation 33: 173-185.

Elegir, G., G. Szakacs, and T.W. Jeffries. 1994. Purification, characterization, and substrate specificities of multiple xylanases from Streptomyces sp. strain B-12-2. Applied and Environmental Microbiology 60: 2609-2615.

Environmental Remediation Technology. 1996. Sneezy clean: Horseradish peroxidase. 4: 11.

Eriksson, K.-E.1980. Development of biotechnology within the pulp and paper industry. Int. Cogr. Pure Appl. Chem. (IUPAC), 27th, Helsinki, pp. 331-337. Pergamon, Oxford. 
Eriksson, K. -E. 1988. Microbial delignification - basics, potentials and applications. Biochemistry and Genetics of Cellulose Degradation. pp. 285-302.

Finstein, M. S. 1989. Composting solid waste: Costly mismanagement of a microbial ecosystem. ASM News 55: 599-602.

Finstein M. S. and J. A. Hogan. Integration of composting process microbiology, facility structure and decision-making. Science and Engineering of Composting. pp. 1-23. In: Science and Engineering of Composting: Design, Environmental, Microbiological and Utilization Aspects. (eds. H. A. J. Hsitink and H. M. Keener). Renaissance Publications. Worthington, $\mathrm{OH} 728 \mathrm{p}$.

Finstein, M. S., F. C. Miller, and P. F. Strom. 1986. Monitoring and evaluating composting process performance. Journal. Wat. Poll. Control. Fed. 58: 272-278.

Finstein, M. S., F. C. Miller, P. F. Strom, S. T. MacGregor, and K. M. Psarianos. 1983. Composting ecosystem management for waste treatment. Biotechnology 1: 347-353.

Fogarty, A. M. and O. H. Tuovinen. 1991. Microbiological degradation of pesticides in yard waste composting. Microbiological Reviews 55: 225-233.

Fogel, R. and K. Cromack. 1977. Effect of habitat and substrate quality on Douglas fir (Pseudotsuga menziesii) litter decomposition in western Oregon. Can. J. Bot. 55: 16321644.

Fox, J.F. and K. Van Cleve. 1983. Relationship between cellulose decomposition, Jenny's K value, forest-floor nitrogen, and soil temperature in Alaskan taiga forests. Can. J. For. Res. 13: 789-794.

Frankland, J.C., J. N. Heger, and M. J. Swift. 1982. Decomposer basdidiomycetes: their biology and ecology. Brit. Myco. Soc. Symp. 4 Cambridge Univ. Press. 355 p.

Frankos, N. H. , F. Gouin, L. J. Sikora. 1982. Using woodchips of specific species in composting. Biocycle 23: 38-40.

Gatliff, E. G. 1995. Series of papers on phytoremediation.

Gauthier, J. J., J. A. Lushington, T. W. Federle, D. D. Jones, J. R. O'Brien, and D. A. McMillon. 1983. Biochemical changes occurring during composting in a static pile and an in-vessel system. Annu. Madison Conf. Appl. Res. Prac. Munic. Ind. Waste, 6th. pp. $379-401$.

Gilardi, G., L. Abis, and A. E. G. Cass. 1994. Wide-line solid-state NMR of wood: Proton relaxation time measurements on cell walls biodegraded by white-rot and brown-rot fungi. Enzyme Microb. Technol. 16: 676-682. 
Gilbertson, R.L. 1980. Wood-rotting fungi of North America. Mycologia 72: 1-49.

Gilbertson, R.L. and L. Ryvarden. 1986. North American polypores. Vol. 1. Abortiporus - Lindtmeria. $433 \mathrm{p}$.

Godshalk, G. L. and R. G. Wetzel. 1977. Interactions between sediments and freshwater (H. L. Goltermann, ed.) pp. 258-264. The Hague: B. V. Publishers.

Godshalk, G.L. and R.G. Wetzel, 1978a. Decomposition of aquatic angiosperms. II. Particulate components. Aquatic Botany 5: 301-327.

Godshalk, G.L. and R.G. Wetzel, 1978b. Decomposition of aquatic angiosperms. III. Zostera marina L. and a conceptual model of decomposition. Aquatic Botany 5: 329354.

Haimann, R. A. 1995. Fungal technologies for the treatment of hazardous waste. Environmental Progess 14: 201-203.

Harkness, G. E., C. C. Reed, C. J. Voss, C. I. Kunihiro. 1994. Composting in the Magic Kingdom. Water, Environment and Technology. Vol. 6.

Harmon, M. E. 1982. Decomposition of standing trees in the Southern Appalachian Mountains. Oecologia 52: 214-215.

Harmon, M.E., J.F. Franklin, F.J. Swanson, P. Sollins, S.V. Gregory, J.D. Lattin, N.H. Anderson, S.P. Cline, N.G. Aumen, J.R. Sedell, G.W. Lienkaemper, K. Cromack, Jr., and K.W. Cummins. 1986. Ecology of coarse wood debris in temperate ecosystems. Adv. Ecol. Res. 15: 133-302.

Henriksson, G., P. Ander, B. Pettersson, G. Pettersson. 1995. Cellobiose dehydrogenase (cellobiose oxidase) from Phanerochaete chrysosporium as a wooddegrading enzyme. Studies on cellulose, xylan and synthetic lignin. Appl. Microbiol. Biotechnol. 42: 790-796.

Herric, F.W. and Hergert, H.L. 1977. Utilization of chemicals from wood: retrospect and prospect. The structure, biosynthesis and degradation of wood. Recent Adv. Phytochem. 2: 443-515.

Heyward, F. and R.M. Barnette. 1936. Field characteristics and partial chemical analyses of the humus layer of longleaf pine forest soils. Florida Agr. Expt. Sta. Bull. $302,27 \mathrm{p}$.

Higashida, S., Y. Hirai, and I. Ohsaki. 1982. Some characteristics of wood wastes as raw materials of bark manure. Soil Sci. Plant Nutr. 28: 281-285. 
Higgins, A. J., M. E. Singley, N. Nocitra, K. Callanan, B. Whitson, and A. Singh. 1980. Shredded rubber tires as a bulking agent. Compost Science/Land Utilization 21: 2023.

Hinchman, R. and C. Negri. 1994. The grass can be greener on the other side of the fence. Argonne National Laboratory. Logos 12: 8-11.

Hogan, J. A., F. C. Miller, and M. S. Finstein. 1989. Physical modeling of the composting ecosystem. Applied and Environmental Microbiology 55: 1082-1092.

Horwitz, E.P., M.L. Dietz, and D.E. Fisher. 1990. Extraction of strontium from nitric acid solution using Dicyclohexano-18-Crown-6 and its derivatives. Solvent Extraction and lon Exchange 8:557-572.

Huang, S. 1992. Biodegradation of pentachlorophenol in a fluidized bed bioreactor. Air \& Waste Management Association. 85th Annual Meeting \& Exhibition. pp. 1-16.

Jenny, $H$. 1950. Causes of the high nitrogen and organic matter content of certain tropical forest soils. Soil Science 69: 63-69.

Jenny, H., S.P. Gessel, and F.T. Bingham. 1949. Comparative study of decomposition rates of organic matter in temperate and tropical regions. Soil Sci. 68: 419-432.

Jeris, J. S. and R. W. Regan. 1973a. Controlling environmental parameters for optimum composting. 1. Experimental procedures and temperature. Compost Science. Jan.-Feb., pp. 10-15.

Jeris, J.'S. and R. W. Regan. 1973b. Controlling environmental parameters for optimum composting. II. Moisture, free air space and recycle. Compost Science. Mar.Apr., pp. 8-15.

Jodice, R., R. Barberis, M. Consiglio and E. Roletto. 1984. Composting bark and agroindustrial sludges. Biocycle 25: 36-38.

Kaarik, A.A. 1974. Decomposition of wood. In biology of plant mitter decomposition. Vol. 1 Edited by C. H. Dickinson and G.J.F. Pugh. Academic Press. London. pp. 129174.

Kakezawa, M., A. Mimura, and Y. Takahara. 1990. A two-step composting process for woody resources. Journal of Fermentation and Bioengineering 70: 173-176.

Kakezawa, M., T. Nishida, and Y. Takahara. 1992. Structural characteristics of humic acids extracted from woody composts by two-step composting process. Soil Sci. Plant Nutr. 38: 85-92. 
Keehan, K. R. and W. E. Sisk. 1992. Composting of explosives-contaminated soils at a national priority list site. Gas, Oil, Environ. Biotechnol. IV (Pap. Int. Symp.), 4th. pp. 227-237.

Kinner, et. al. 1993. Reverse-burn gasification for treatment of hazardous wastes: Contaminated soil, mixed wastes, and spent activated carbon regeneration. Environ. Sci Tech 27.

Koch, P. 1972. Utilization of Southern Pines. Agriculture Handbook No. 420, Vol I, U.S.D.A., Superintendent of Documents, Washington, D.C., pp 238, 582.

Kuelske, K.J. WSRC-RP-95-1536. Removal Site Evaluation Report for HP-52 Outfall. Westinghouse Savannah River Company, Savannah River Site, Aiken, SC 29808, August 1995.

Kurek, B., B. Monties, and E. Odier. 1990. Influence of the physical state of lignin on its degradability by the lignin peroxidase of Phanerochaete chrysosporium. Enzyme Microb. Technol. 12: 771-777.

Lambert, R.L., G.E. Lang, and W.A. Reiners. 1980. Loss of mass and chemical change in decaying boles of a subalpine balsam fir forest. Ecology 61: 1460-1473.

Landeen, D. S. and R. M. Mitchell. 1986. Radionuclide uptake by trees at a radwaste pond in Washington state. Health Physics 50: 769-774.

Laudelot, $\mathrm{H}$. and J. Meyer. 1954. Les cycles d'elements minearaux et de matiere organique en foret equatoriale congolaise. Trans 5 th Int. Congr. Soil Science 2: 267272.

Leatham, G. F., G. C. Myers, and T. H. Wegner. 1990. Biomechanical pulping of aspen chips: energy savings resulting from different fungal treatments. Tappi Journal 73: $197-200$.

Lin, J.-E., D. C. N. Chang, G. -J. Shen, and H. Y. Wang. 1991. Correlations among several screening methods used for identifying wood-decay fungi that can degrade toxic chemicals. Biotechnology Techniques 5: 275-280.

Lindfors, L. 1979. Study of composting of sludge and bark. Conf. Int. Trade Fair Recycling, Refuse Collect. Waste. Treat. pp. 307-323.

Lomax, K. M., N. E. Collins, Jr., and C. M. Denneny. 1984. Simulating mushroom compost heat production. Biocycle. 25: 38-40. 
Lonsane, B. K., N. P. Ghildyal, S. Budiatman and S. V. Ramakrishna. 1985.

Engineering aspects of solid state fermentation. Enzyme Microb. Technol. 7: 258-265.

Lowe, E. D. and D. R. Buckmaster. 1995. Dewatering makes big difference in compost strategies. Biocycle 36: 78-82.

MacGregor, S. T., F. C. Miller, K. M. Psarianos, and M. S. Finstein. 1981. Composting process control based on interaction between microbial heat output and temperature. Applied and Environmental Microbiology 41: 1321-1330.

Machuca, A. and N. Duran. 1993. Phenol oxidases production and wood degradation by a thermophilic fungus Thermoascus aurantiacus. Applied Biochemistry and Biotechnology 43: 37-44.

Magalhaes, A. M. T., P. J. Shea, M. D. Jawson, E. A. Wicklund, and D. W. Nelson. 1993. Practical simulation of composting in the laboratory. Waste Management \& Research 11: 143-154.

Malik, N. P. S., G. G. Rucker, and M. G. Looper. 1995. Incineration of low level radioactive vegetation for waste volume reduction. Waste management ' 95 . WSRCMS-94-0431X.

Martin, A. M., J. Evans, D. Porter, and T. R. Patel. 1993. Comparative effects of peat and sawdust employed as bulking agents in composting. Resource Technology 44 : 65-69.

Mattson, K.G., W.T. Swank, and J.B. Waide. 1987. Decomposition of woody debris in regenerating, clear-cut forest in the southern Appalachians. Can. J. For. Res. 17: 712721.

McBain, A., F. Cui, L. H. and J. N. R. Ruddick. 1995. The microbial degradation of chlorophenolic preservatives in spent, pressure-treated timber. Biodegradation 6: 4755.

McGinnis, J. 1958. Forest litter and humus types of East Tennessee. M. S. Thesis, University of Tennessee.

Meentmeyer, V. 1978. Ecology 59: 465.

Meentmeyer, V. and B. Berg 1986a. Can. J. For. Res. 24:1771-1781.

Meentmeyer, V. and B. Berg. 1986b. Regional variation in rate of mass loss of Scots pine needle litter in Swedish pine forests as influenced by climate and litter quality. Scand. J. For. Res. 1: 167-180. 
Melillo, J. M., J. D. Aber, and J. F. Muratore. 1982. Nitrogen and lignin control of hardwood leaf litter decomposition dynamics. Ecology 63: 621-626.

Metz, L.J. 1952. Weight and nitrogen and calcium content of the annual litter fall of forests in the South Carolina Piedmont. Soil Sci. Soc. Am. Proc. 16:38-41.

Metz, L.J. 1954. Forest floor in the Piedmont Region of South Carolina. Soil Sci. Soc. Am. Proc. 18: 335-338.

Metz, L.J. and C.G. Wells. 1965. Weight and Nutrient Content of the Aboveground Parts of Some Loblolly Pines. USDA Forest Service Res. Pap. SE-17, Southeastern Forest Exp. Sta., Asheville, N.C. , 20 p.

Micales, J. A. 1995. Oxalate decarboxylase in the brown-rot wood decay fungus Postia placenta. Materials and Organisms 29: 177-186.

Michel, Jr., F.C., C. A. Reddy, and L. J. Forney. 1995. Microbial degradation and humification of the lawn care pesticide 2,4-dichlorophenoxyacetic acid during the composting of yard trimmings. Applied and Environmental Microbiology 61: 25662571.

Michiels, J., D. De Vleeschauwer, O. Verdonck, and M. De Boodt. 1981. The influence of the additon of some inorganic waste products on the composting of bark. Resources and Conservation 6: 329-337.

Mikola, P. 1960. Comparative experiment on decomposition rates of forest litter in southern and northern Finland. Oikos 11: 161-166.

Miller, R.L. et al. 1995. extraction of cesium and strontium in hydrocarbon solvents using tetra-C-Alkyl Cobalt Dicarbollide. Solvent Extraction and Ion Exchange 13: 813829.

Monk, C.D. 1966. Root-shoot dry weights in loblolly pine. Bot. Gaz. 127: 246-248.

Moore, P. D. 1995. Nitrogen cycle provides fertile ground for ecologists. Current Contents. pp.3-6.

Mote, C. R. and C. L. Griffis. 1982. Heat production by composting organic matter. Agricultural Wastes 4: 65-73.

Mudgett, R. E. 1986. Solid-state fermentations. Manual of Industrial Microbiology and Biotechnology. Chapter 7, pp. 66-83. 
Murphy C.E. Jr. 1994. Vegetation Concentration and Inventory of Metals and Radionuclides in the Old F-Area Seepage Basin, 904-49G (U). WSRC-TR-94-0361, Westinghouse Savannah River Company, Savannah River Site, Aiken, SC, 15 p.

Murray, C. M., J. L. Thompson, and J. S. Ireland. 1991. Process control improvements at composting sites. Biocycle 32: 54-58.

Myttenaere, C., W. R. Schell, Y. Thiry, L. Sombre, C. Ronneau and J. van der Stegen de Schrieck, 1993. Modelling of Cs-137 cycling in forests: recent developments and research needed. The Science of the Total Environment 136: 77-91.

Nakasaki, K., J. Kato, T. Akiyama, and H. Kubota. 1987. A new composting model and assessment of optimum operation for effective drying of composting material. J. Ferment. Technol. 65: 441-447.

N'Dayegamiye, A. and D. Isfan. 1991. Chemical and biological changes in compost of wood shavings, sawdust and peat moss. Can. J. Soil Sci. 71: 475-484.

Niemela, T., P. Renvall, and R. Penttila. 1995. Interactions of fungi at late stages of wood decomposition. Ann. Bot. Fennici 32: 141-152.

Niku-Paavola, M. -L., E. Karhunen, A. Kantelinen, L. Viikari, T. Lundell, and A. Hatakka. 1990. The effect of culture conditions on the production of lignin modifying enzymes by the white-rot fungus Phlebia radiata. Journal of Biotechnology 13: 211-221.

Nyamai, D. O. 1992. Investigations on decomposition of foliage of woody species using a perfusion method. Plant and Soil 139: 239-245.

Nye, P.H. 1961. Organic matter and nutrient cycles under moist tropical forest. Plant and Soil 13: 333-346.

Olson, J.S. 1963. Energy storage and the balance of producers and decomposers in ecological systems. Ecology 44: 322-331.

O'Reilly, K. T., R. Kadakia, R. A. Korus, and R. L. Crawford. Utilization of immobilized bacteria to degrade aromatic compounds common to wood-treatment wastewaters. Wat. Sci. Tech. 20: 95-100.

Parekh, S. R., R. S. Parekh, and M. Wayman. 1987. Fermentation of wood-derived acid hydrolysates in a batch bioreactor and in a continous dynamic immobilized cell bioreactor by Pichia stipitis R. Process Biochemistry 22: 85-91.

Parekh, S. R., R. S. Parekh, and M. Wayman. 1989. Ethanolic Fermentation of woodderived cellulose hydrolysates by Zymomonas mobilis in a continuous dynamic immobilised biocatalyst bioreactor. Process Biochemistry 24: 88-91. 
Parnas, H. 1975. Model for decomposition of organic materials by microorganisms. Soil Biol. Biochem. 7: 161-169.

Parten, S. 1994. Using waste wood chips to treat septage. Biocycle 35: 74-76.

Paszczynski, A. and R. L. Crawford. 1995. Potential for bioremediation of xenobiotic compounds by the white-rot fungus Phanerochaete chrysosporium. Biotechnol. Prog. 11: 368-379.

Pellinen, J., J. Abuhasan, T. W. Joyce, and H. -M. Chang. 1989. Biological delignification of pulp by Phanerochaete chrysosporium. Journal of Biotechnology 10: 161-170.

Petruska, J. A., D. E. Mullins, R. W. Young, and E. R. Collins, Jr. 1985. A. benchtop system for evaluation of pesticide disposal by composting. Nuclear and Chemical Waste Management 5: 177-182.

Pierce, R. A. and J. R. Smith. 1995. Nitric-phosphoric acid oxidation of organic waste materials (U). WSRC-MS-95-0080. Westinghouse Savannah River Company.

Polan, P., J. Gagnon, and J. P. Jones. 1993. Use of sludge compost from wastewater as a substrate for containerized forest plants. Can. J. Civ. Eng. 20: 518-527.

Psarianos K. M., S. T. MacGregor, F. C. Miller, and M. S. Finstein. 1983. Design of composting ventilation system for uniform air distribution. Biocycle 24: 27-31.

Puls, J., C. Ayla, and H. H. Dietrichs. 1983. Chemicals and ruminant feed from lignocefluloses by the steaming-extraction process. Journal of Applied Polymer Science: Applied Polymer Symposium 37. pp. 685-695.

Rao, N., H. E. Grethlein, and C. A. Reddy. 1995. Effect of C/N ratio and moisture content on the composting of poplar wood. Biotechnology Letters 17: 889-892.

Rayner, A.D.M. and L. Boddy. 1988. Fungal decomposition of wood. Its biology and ecology. John Wiley \& Sons. New York. 587 p.

Riggle, D. 1994. Mastering the way to home composting. BioCycle 35: 37-39.

Samuelsson, J., L. Gustafsson, and T. Ingelog. 1994. Dying and dead trees: a review of their importance to biodiversity. Swedish Threatened Species Unit. Uppsala, Sweden. 
Sargantanis, J, M. N. Karim, V. G. Murphy, D. Ryoo, and R. P. Tengerdy. 1993. Effect of operating conditions on solid substrate fermentation. Biotechnology and Bioengineering 42: 149-158.

Schell, W.R., I. Linkov, C. Myttenaere, and B. Morel. 1996. A dynamic model for evaluating radionuclide distribution in forest from nuclear accidents. Health Physics 70.

Schowalter, T.D. 1992. Heterogenity of decomposition and nutrient dynamics of oak (Quercus) logs during the first 2 years of decomposition. Can. J. For. Res. 22: 161166.

Schuman, G. E. and S. E. Belden. 1991. Decomposition of wood-residue amendments in revegetated bentonite mine spoils. Soil Sci. Soc. Am. J. 55: 76-80.

Schwarze, F. W. M. R., D. Lonsdale, and C. Mattheck. Detectability of wood decay caused by Ustulina deusta in comparison with other tree-decay fungi. 1995. Eur. J. For. Path. 25: 327-341.

Shanks, R. E. and J. S. Olson. 1961. First-year breakdown of leaf litter in southern Appalachian forests. Science 134: 194-195.

Sjostrom, Eero, 1981. Wood Chemistry: Fundamentals and Applications. Academic Press, New York. 223p

Smith, J. R. 1993. Air-nitric acid destructive oxidation of organic wastes. WSRC-MS93-169. Westinghouse Savannah River Company. pp. 1-8.

Smith, M. and G. Boley. 1993. Engineering and economic analysis of processing used wood pällets, etc. to fuel. USDA Forest Service, Forest Products Laboratory Report NTIS \# 53-5680-3-440.

Solbraa, K., M. D. Sant, A. R. Selmer-Olsen, and H. R. Gislerod. 1983. Composting soft and hardwood barks. Biocycle 24: 44-48

Sollins, P. 1982. Input and decay of coarse woody debris in coniferous stands in western Oregon and Washington. Can. J. For. Res. 12: 18-28.

Spohn, E. 1970. Composting by artifical aeration. Compost Science 11: 22-23.

Still, S. M., M. A. Dirr, and J. B. Gartner. 1974. Effect of nitrogen and composting on decomposition of barks from four hardwood species. Forest Product J. 24: 54-56.

Stombaugh, D. P. and S. E. Nokes. 1996. Development of a bioligically based aerobic composting simulation model. Transactions of the ASAE 39: 239-250. 
Suberkropp, K., G. L. Godshalk, and M. J. Klug. 1976. Ecology 57: 720.

Tenney, F. G. and S. A. Waksman. 1929. Composition of natural organic materials and their decomposition in the soil. IV. The nature and rapidity of decomposition of the various organic complexes in different plant materials under aerobic conditions. Soil Science 28: 55-X.

Torres, J. A. 1994. Wood decomposition of Cyrilla racemiflora in a tropical montane forest. Biotropica 26: 124-140.

Van Cleve, K. 1974. Organic matter quality in relation to decomposition. In soil organisms and decomposition in tundra. Edited by A.J. Holding, O.W. Heal, S.F. MacLean, and P.W. Flanagan. Biome Steering Committee, Stockholm, Sweden. pp. 311-324.

Van Lier, J. J. C., J. T. Van Genkel, G. Straatsma, J. P. G. Gerrits, and L. J. L. D. Van Griensven. 1994. Composting of mushroom substrate in a fermentation tunnel.: compost parameters and a mathematical model. Netherlands J. Agric. Sci. 42: 271 292.

Viel, M., D. Sayag, A. Peyre, and L. Andre. 1987. Optimization of in-vessel cocomposting through heat recovery. Biological Wastes 20: 167-185.

Vojtech, R. J. 1993. An aerial radiological survey of the Savannah River Site and surrounding area October-November 1991.

Wahlenberg, W.G. 1960. Loblolly Pine. The School of Forestry, Duke University, Durham, N.C., p 270.

Wayman, M. and S.R. Parekh. 1990. Biotechnology of Biomass Conversion, Prentice Hall, New Jersey.

Williams, R. T., P. S. Ziegenfuss, G. B. Mohrman, and W. E. Sisk. 1989. Composting of explosives and propellant contaminated sediments. Hazard. Ind. Waste 21: 599611.

WSRC-RP-95-537 Rev. 1, RFI/RI Work Plan for the R-Reactor Seepage Basins/1084R Overflow Basin Operable Unit, Westinghouse Savannah River Company, Savannah River Site, Aiken, SC 29808. May 1995.

WSRC-RP-95-1534. Removal Site Evaluation Report for Warner's Pond. Westinghouse Savannah River Company, Savannah River Site, Aiken, SC 29808, August 1995. 